\title{
World Exhibitions and Changes in the Urban Morphology of Seville
}

Lea Petrović Krajnik ${ }^{1}$ | Damir Krajnik ${ }^{2}$ | Vladimir Petrović ${ }^{3}$

Received: 2019-07-17 | in its final version: 2020-06-21

\begin{abstract}
The aim of this article is to identify and interpret with mathematical exactitude the difference between the effects of interventions that were carried out in the urban structure morphology of Seville on the occasion of organising world exhibitions, with an emphasis on the operationalisation of three levels of resolution. The comparative method was used to analyse changes in the generative elements of the basic morphological unit, urban tissue and components of the urban structure composition generated by interventions at the locations of the exhibitions held in 1929 and 1992. The analysis was performed by metric and/or topological quantification, or qualification of the generative elements built diachronically. Third level indicators point to the possibility of quantification and qualification of interaction indicators of urban structures with urban systems at the fourth level of resolution. The application of more than twenty indicators of the urban morphology elements built diachronically on the occasion of the same type of event (a world exhibition), on the same object (Seville), enables the operationalization and scientific evaluation of the spatial changes. Since current studies focus more on analysing of urban morphology at different levels of resolution this article attempts to contribute to urban morphology theory by linking different levels of resolution with a larger number of indicators. The approach to the third level resolution analysis specifically points to the originality of the research, trying to give that level greater significance and to extend the basis for analysing the fourth level of urban morphology resolution.
\end{abstract}

Keywords: Composition of urban structure; indicators; levels of resolution; quantitative methods

Citation

Petrović Krajnik, L. et al. (2020). World Exhibitions and Changes in the Urban Morphology of Seville. ACE: Architecture, City and Environment, 15(44), 8762. DOI: http://dx.doi.org/10.5821/ace.15.44.8762

${ }^{1}$ Ph.D., Architect, Associate Professor at the Department of Urban Planning, Spatial Planning and Landscape Architecture, Faculty of Architecture, University of Zagreb (ORCID: 0000-0002-4636-7532; WoS Researcher ID: ABA-9281-2020, Scopus Author ID: 36179675900); ${ }^{2}$ Ph.D., Architect, Full Professor at the Department of Urban Planning, Spatial Planning and Landscape Architecture, Faculty of Architecture, University of Zagreb (ORCID: 0000-0002-8040-3533; Scopus Author ID: 24528846300); ${ }^{3}$ Architect and Urban planner. Contact e-mail: lea.petrovic@arhitekt.hr 


\section{Introduction}

World and international exhibitions are the mega-events that last the longest and attract the largest number of visitors compared to other types of events. Although the roots of world exhibitions date back to the time of ancient history', the first modern world exhibition was held in London², in the Crystal Palace in Hyde Park in 1851 under the name the Great Exhibition of the Works of Industry of All Nations.

From their very beginnings, modern world and international exhibitions have left their host cities with significant architectural achievements that have become symbols of the exhibitions, as well as emblematic buildings ${ }^{3}$ that make the city recognizable at the world level. During the 19th and 20th centuries, the holding of world exhibitions greatly influenced the shaping of host cities, whether through the expansion and development of new urban axes and areas or the urban transformation of certain areas of the city ${ }^{4}$. Besides positioning the city on a national and international level, some world exhibitions held in the $19^{\text {th }}$ century were used as the means for implementing urban reforms, especially in the case of exhibition in the $20^{\text {th }}$ century.

A great many large cities, as well as smaller ones, have organised world and international exhibitions. Some European cities such as Paris, Brussels, Barcelona and London, have hosted several world and international exhibitions, indicating their great importance for the host city. Seville was chosen for this research as an example of a medium-sized city whose two exhibitions, Exposición Iberoamericana 1929 - 1930 and World Exhibition - EXPO'92, served as the means for bringing about planned urban reforms and overall development.

Of the four levels of resolution of urban morphology ${ }^{5}$ (Curdes, 1997; Scheer, 2016), research on the impact of world exhibitions on the planimetric characteristics of Seville's urban morphology was analysed at three levels of resolution. The fourth level of resolution, which relates to the regional and spatial aspects of urban morphology, goes beyond the scope of this article. ${ }^{6}$

\footnotetext{
${ }^{1}$ Although the need to gather and exchange goods is characteristic of the entire development of humanity, we would like to highlight the cities of the Hellenic world, Mesopotamia and ancient Egypt in which people from different continents met and gathered on the occasion of lucrative events in order to exhibit and exchange their products and services. The roots of the phenomenon of world exhibitions could be linked with non-lucrative activities like the exhibition of rare artefacts during festivals. (Pinot de Villechenon, 2000).

${ }^{2}$ The London exhibition in 1851 was the first Great Exhibition open to the international scene. The Crystal Palace with its iron and glass architecture was a paradigm for exhibition buildings in 19th century (Busquets, 2005). The predecessors of today's world exhibitions, besides medieval fairs, were exhibitions of works of art and crafts, exhibitions of art and industrial products, and industrial exhibitions organised at a regional and national level. (Pinot de Villechenon, 2000).

3 The World Exhibition held in Paris in 1889 was a confirmation of the highest achievements in the construction of halls and steel structures in the 19th century, which were materialized in the construction of the Eiffel Tower. Besides the Eiffel Tower being a symbol of "exhibition", it become a permanent symbol of Paris. (Busquets, 2005; Petrović, 2009).

${ }^{4}$ Four major events have taken place in Barcelona: the Exposición universal de Barcelona 1888, the Exposición International de Barcelona 1929, the 25th Olympic Games and the 2004 Universal Forum of Cultures, which significantly influenced the shaping of the city. Busquets (2005) points out three groups of scales of activity in Barcelona's urban development process: urban rehabilitation (small scale direct interventions in urban space and green areas), urban restructuring (strategies of broader scope such as the reorganisation of the road network and areas of new centrality), and keys structuring the form of the morphological organization of the city.

${ }^{5}$ At the first level of resolution, the generative elements form a fundamental morphological unit, at the second resolution level they generate the urban tissue texture patterns and urban tissue component networks, and at the third resolution level they generate the composition of the urban structure. The fourth level of resolution involves the positioning of the entities of the urban system.

${ }^{6}$ The fourth level of resolution includes the ranging of structures according to size, determining the degree of centrality and the coefficient of nodality (Petrović, Petrović Krajnik, \& Krajnik, 2014; Petrović Krajnik, Petrović, \& Krajnik, 2017) as well as other indicators of spatial changes in urban structures as entities of the urban system (Niño Soto, Badillo Jimenez, \& Dávila Cordido, 2019).
}

ACE, 15 (44) CC BY-ND 3.0 ES | UPC Barcelona, España | World Exhibitions and Changes in the Urban Morphology 
The purpose of this paper is to complement the analysis of the third level resolution of urban structure morphology with quantitative and qualitative indicators so as to enable an operational analysis of the morphology structure at all three levels. The aim of the article is to identify, interpret and compare, with mathematical exactitude and from a diachronic perspective ${ }^{7}$ (covering a period of 60 years), the difference in the effects on the morphology of urban structures of the same object (the city of Seville) that were brought about by the organisation of large events of the same type (world exhibitions).

\section{Research methodology}

An analysis of changes in the urban morphology was performed by comparing the indicators of the relations between the generative elements ${ }^{8}$ (a total of 24 indicators) of all three levels of urban structure resolution. At the lowest level, the level of the analysis of fundamental morphological units, the indicators of the interrelationships between the formative elements of the representative samples, shown in the relation matrix, are graphically represented and calculated. At a higher level, the level of urban tissue, the constructive elements of the urban tissue are graphically represented and calculated on representative samples. At the third level, the composition level of the urban structure, the indicators of changes in the planimetric characteristics of the urban structure composition, brought about by interventions in the city area on the occasion of organising world exhibitions are graphically represented and calculated before the preparatory period of the exhibitions and after the exhibitions.

For the mathematical calculation and interpretation of changes in the urban morphology at the observed levels, graphical representations were made using AutoCAD software. The analysis was performed by topological identification and metric quantification or qualification of the generative elements at each level. A more detailed explanation of the procedure for calculating and comparing indicators is given in Chapter 4.

The comparative analysis was carried out:

- At the first level - by calculating and comparing the relations between the formative elements (plots, streets, buildings and open spaces of the plot) ${ }^{9}$ of fundamental morphological units built for permanent use on the exhibition site;

- At the second level - by calculating and comparing the constructive elements (infrastructure, suprastructure and ecostructure) of the newly built urban tissue that form several identical or different patterns of urban tissue texture included in the urban structure component, and

\footnotetext{
${ }^{7}$ The term "diachronic perspective" means the observation of a particular phenomenon (world exhibitions) and their effect in the space/area of the same city at different times (1929 and 1992).

${ }^{8}$ Generative elements of urban fabrics are plots, streets (parts of the street) and buildings that have variable physical features (properties, characteristics, attributes) and which, through their combinations, form different typological units of urban morphology. The combination of multiple typological units of the same or different features generates an urban tissue texture pattern. Multiple urban tissue texture patterns, along with networks, generate urban tissue components. Multiple urban tissue components generate an urban structure (city) composition, and more entities generate an urban system.

${ }^{9}$ The methodology of a survey of first level features is presented using four variables (plot, street, building and open space / unbuilt part of the plot). The number of matrix variables and the resulting indicators could also be increased by using urban morphology indicators applied and / or cited by authors such as A. Levy (2005) and B. C. Scheer (2016). For an analysis of the features of the urban fabric, the number of variables in the relation matrix of typological units is not limited and can be used as needed: from the "quantum" level (colour, facade treatment, type of building material) to the planimetric indicators shown in the relation matrix of this paper (see diagrams 4.3 .1 and 4.3.2) and other stereometric indicators (García Martín, 2019).
}

ACE, 15 (44) CC BY-ND 3.0 ES | UPC Barcelona, España | World Exhibitions and Changes in the Urban Morphology

of Seville. DOI: http://dx.doi.org/10.5821/ace.15.44.8762 
- At the third level - by calculating, interpreting and comparing the influence of urban structure components on the form and characteristics of the city structure composition by means of indicators of compactness and interaction with the surroundings (Petrović Krajnik, 2011) before the preparatory period of the exhibition and after the exhibition.

World exhibitions occasion large scale interventions that also enable the analysis of higher levels of urban morphology. So, in analysing the impact on changes in urban morphology we start with the wider context of urban structure morphology and then by the method of deduction we descend through the levels of resolution down to the level of fundamental morphological units.

\section{World Exhibitions and the Urban Development of Seville}

Prior to the analysis of changes in urban morphology brought about by interventions in the city on the occasion of the exhibitions, we will start with a brief overview of the historical development of the city since the time of its founding until the end of the $20^{\text {th }}$ century.

The city was founded by the Tartessians in the $9^{\text {th }}$ century BC on the eastern bank of the Baetis River (Guadalquivir) under the name Spal. Later it became the Phoenician colony of Sephala, then the Iberian settlement Hispalis (a fortified city with a forum), and the Roman colony Colonia Iulia Romula Hispalis and the capital of the Baetica province. After the fall of the Roman Empire, it was first conquered by the Vandals, then by the Visigoths, and finally by the Arabs who changed the name of the town to /shbiliya and started to gradually transform its urban structure and organisation. Following the Conquista Cristiana, a period of political and economic consolidation began, so the conditions were created for further architectural interventions in the city area. (Gutkind, 1967)

At the beginning of the $15^{\text {th }}$ century, the Carthusian monastery Santa Maria de las Cuevas was founded, located outside the city walls on the western bank of the Guadalquivir River (Figure 1).

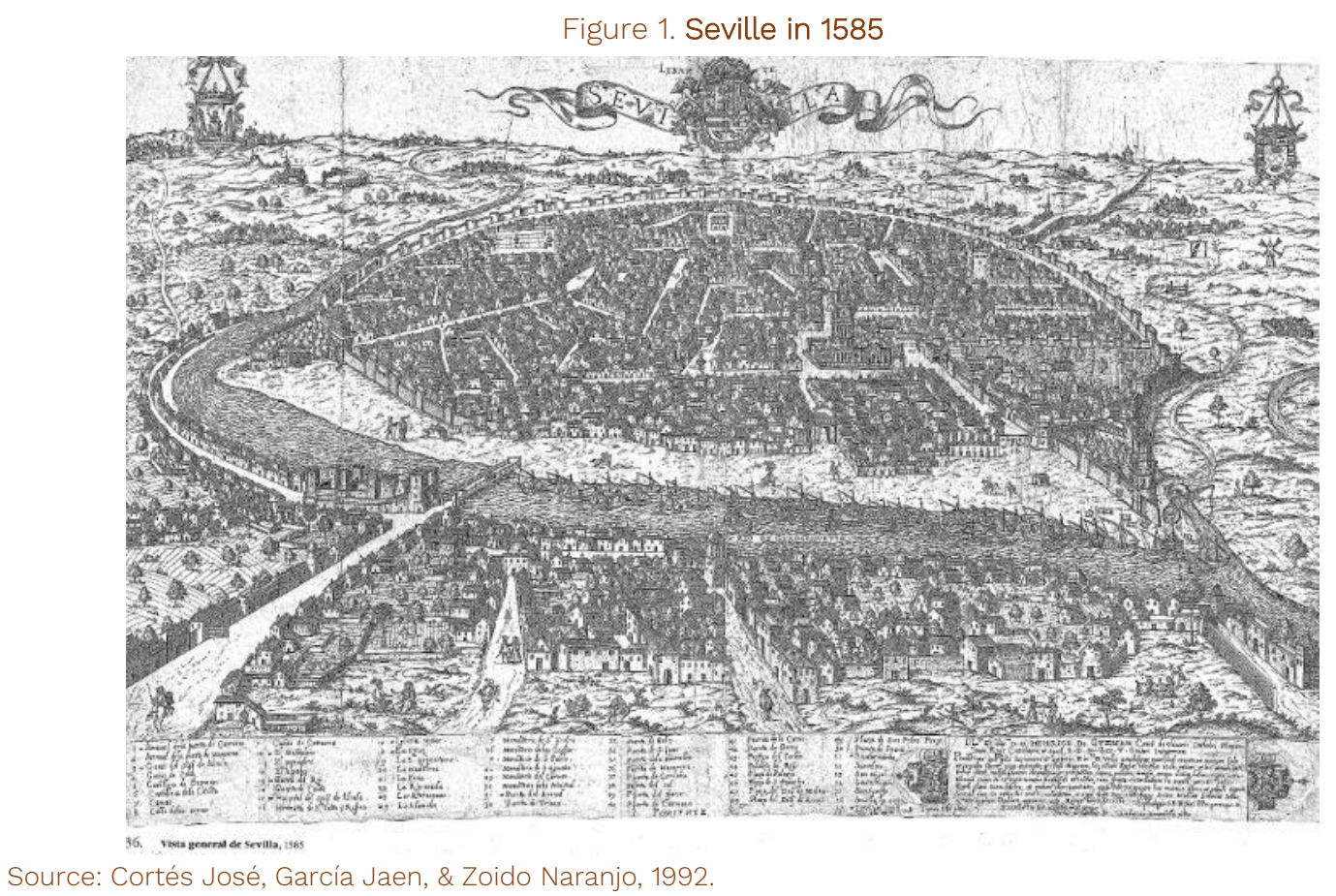

ACE, 15 (4.4) CC BY-ND 3.0 ES | UPC Barcelona, España | World Exhibitions and Changes in the Urban Morphology of Seville. DOI: http://dx.doi.org/10.5821/ace.15.44.8762 
Following the example of France, in the second half of the $19^{\text {th }}$ century the city administration suggested new solutions for sanitary problems intramuros, creating the conditions for opening public spaces and improving the quality of life in the city. In 1869 part of Seville's fortifications were demolished, creating space for the construction of the boulevard (a green promenade), as well as for the enlargement of streets and squares.

The construction of the railway corridor San Jerónimo - Plaza de Armas along the western part of the city nucleus initiated the gradual urbanisation of the northern part of the city (see Figure 2). While the railway barrier limited the radial connection of the historic nucleus with the western parts of the city, interventions to improve navigation and flood protection on the Guadalquivir River provided the impetus for the development of industry along the southern part of the eastern bank of the river (Cortés José, García Jaen, \& Zoido Naranjo, 1992).

New interventions and investments in urban infrastructure caused the migration of the rural population to the city. This growth in the population created a need for additional construction, while the lack of reforms and plans for city expansion was evident through the construction of unplanned, dispersed and unconnected quarters in the suburbs.

Further southward expansion starting in the late $19^{\text {th }}$ century was stimulated by the donation of a significant part of the gardens along Palacio de San Telmo by Infanta María Luisa to enable the development of imposing public green spaces, by the selection of the Exposición Iberoamericana site in the first quarter of the $20^{\text {th }}$ century (see Figure 3) and by expansion plans from the early $20^{\text {th }}$ century.

Figure 2. Map of Seville in 1870

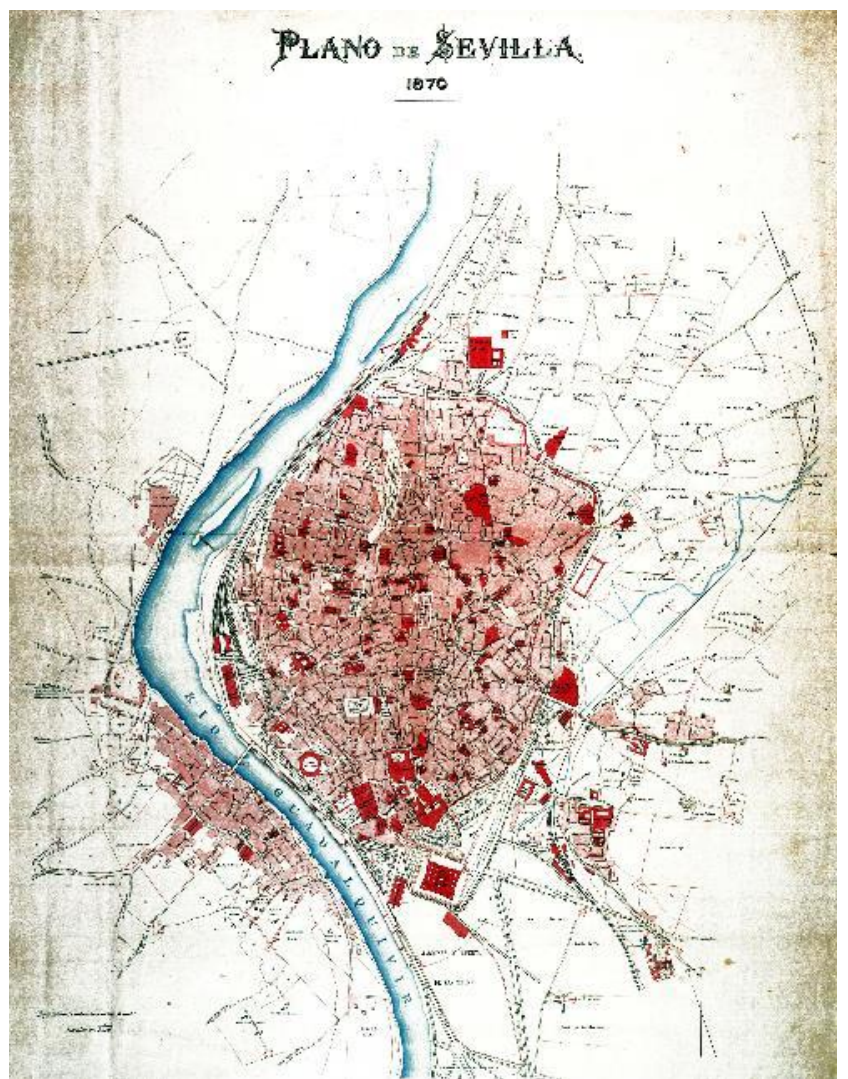

Source: Cortés José, García Jaen, \& Zoido Naranjo, 1992.

ACE, 15 (4.4) CC BY-ND 3.0 ES | UPC Barcelona, España | World Exhibitions and Changes in the Urban Morphology 5 of Seville. DOI: http://dx.doi.org/10.5821/ace.15.44.8762 


\section{ACE Architecture, City and Environment}

E-ISSN $1886-4805$

Figure 3. Map of Seville in 1918

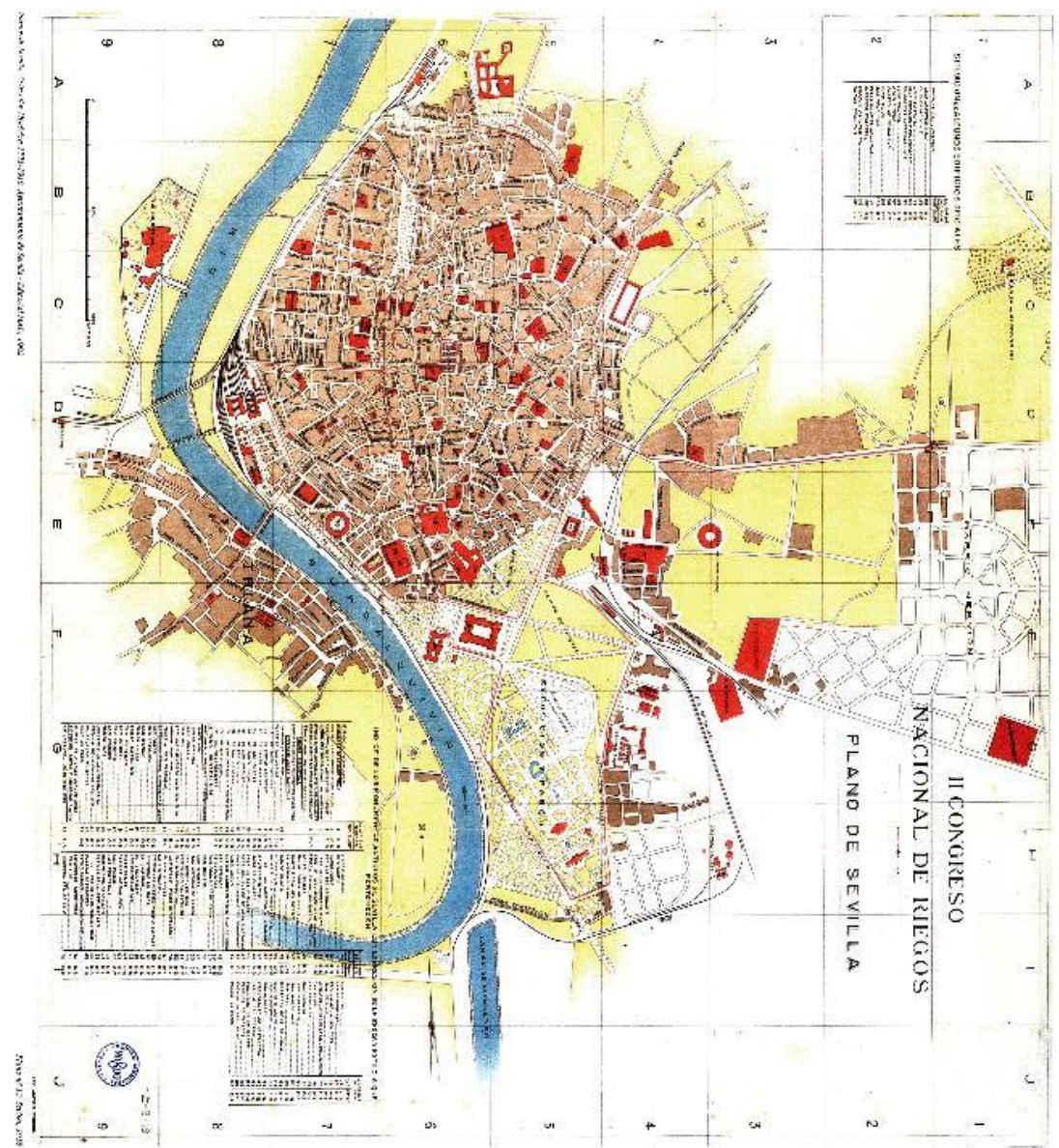

Source: Cortés José, García JaenZoido Naranjo, 1992.

At the beginning of the $20^{\text {th }}$ century, the construction of Canal Alfonso XIII and preparatory works for the organisation of the Exposición Iberoamericana in 1929 on the land along the Palacio de San Telmo enabled the expansion and urbanisation of the southern ${ }^{10}$ and eastern ${ }^{11}$ parts of the city (Figure 4).

The expansion of the urban fabric on the southern part of the western bank ${ }^{12}$ of the Guadalquivir River prompted the construction of the Alphonso XIII bridge in 1926 (Cortés José, García Jaen, \& Zoido Naranjo, 1992, pp. 1-45) as well as the construction of a new bridge, the Puente de los Remedios, and the enlargement of an existing one, the Puente de San Telmo at the end of the 1960s.

\footnotetext{
10 In 1902 a scheme was suggested for a garden city by the Guadaíra River within the project of the extension and urbanisation of la Palmera (Proyecto de Ensanche y Urbanización de la Palmera) that was later carried out within the project Avenida de la Reina Victoria. During the planning of the 1929 Exhibition, the quarters El Porvenir (in the southern part of Parque de María Luisa) and Heliópolis (on the southern side beneath the exhibition area, near the Guadaíra River) were built. (Gerencia de Urbanismo - Ayuntamiento de Sevilla, 2006)

${ }^{11}$ The project of the urbanisation of the eastern part of the city (Proyecto de Urbanización del Cortijo Maestrescuela), drawn up in 1911 by Aníbal González, was not completely carried out. For the accommodation of visitors, the garden city was built as a part of Barrio Nervión, just prior to the Exhibition. (Gerencia de Urbanismo - Ayuntamiento de Sevilla, 2006) ${ }^{12}$ The urban structure also extended to the south of the western bank of the Guadalquivir River. The Triana quarter dates back to ancient times as evidenced by the old plans of the city. At the beginning of the 20th century, expansion and development plans were developed covering the southwestern shore of the Gadalquivir River. For more details see: Gerencia de Urbanismo - Ayuntamiento de Sevilla, 2006.
} 

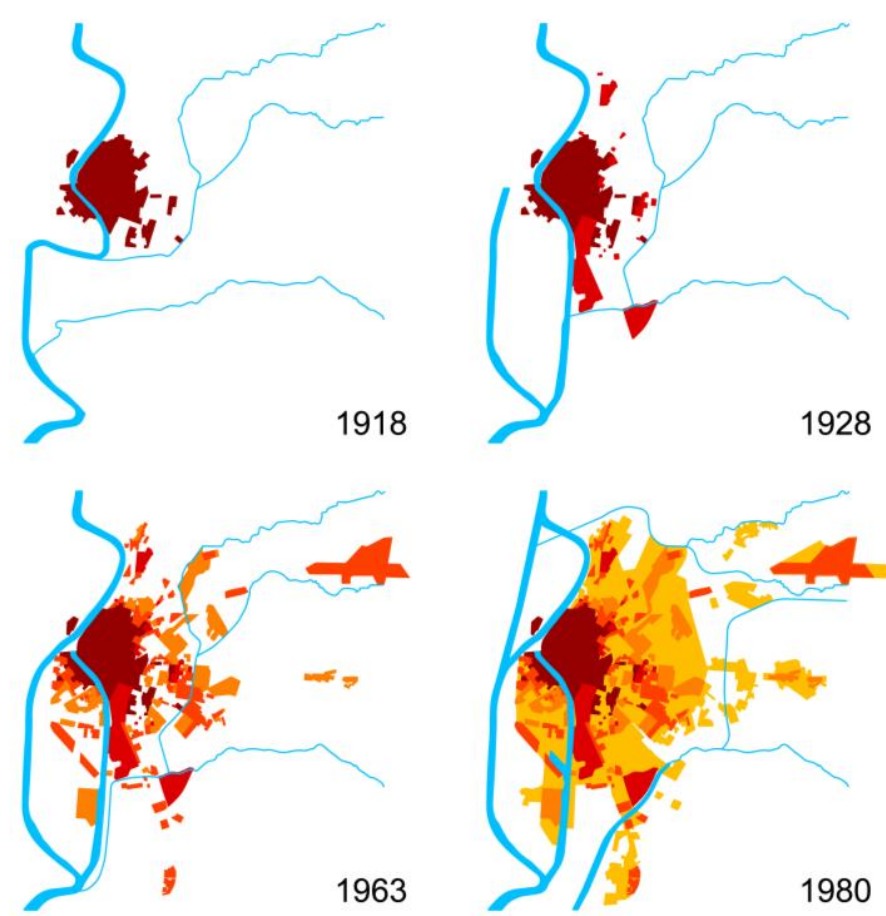

1980
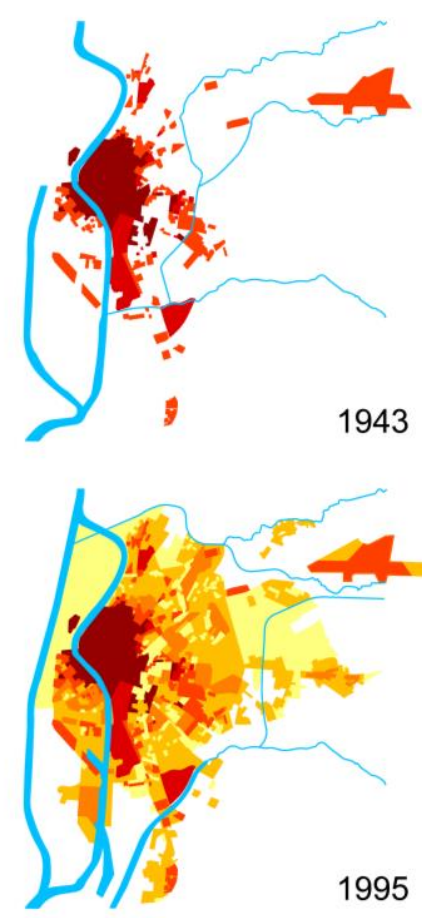

1995 $5 \mathrm{~km}(1$

Source: Author's elaboration based on Plan General de Ordenación Urbana 2006.

Demographic growth, intensive and accelerated industrialisation, the progressive occupation of the city territory as well as the necessity of solving existing problems ${ }^{13}$ in the urban structure brought about a need for complex planning documentation ${ }^{14}$ (Gerencia de Urbanismo - Ayuntamiento de Sevilla, 2006).

From the late 1950s and during the 1960s, the city became a magnet for rural Andalusian emigration. New high-density residential districts were built through public initiatives, while the historic centre gradually underwent a process of degradation. Government projects focused on the construction of the industrial fabric (industrial parks and industrial zones) as defined by spatial planning documents from 1963 (Marchena Gómez, \& Hernández Martín, 2016).

\footnotetext{
${ }^{13}$ The problems in the urban structure were a lack of circular connection of the peripheral settlements, lack of parks and gardens in the city centre, the inadequate functioning of the existing railway routes etc.

${ }^{14}$ In 1946 the first preparatory land-use plan, the Plan General de Ordenación Urbana (PGOU), was drawn up which should have provided for the prestige and functionality of the city at the national and regional level. On the basis of guidelines in this plan, a new preparatory land-use plan, PGOU, was elaborated in 1963 with an emphasis on solving the problem of transport links. According to the plan, industrial parks were built, and industrial zones were provided for, as well as the port industrial zone. The residential zone was extended to the north and north-east where residential areas were established.
}

ACE, 15 (44) CC BY-ND 3.0 ES | UPC Barcelona, España | World Exhibitions and Changes in the Urban Morphology 
Under the influence of powerful transformation, demographic growth, economic development and industrialisation in the 1970s, some illegal constructions were made at the boundaries of the city area. This pointed to a need for higher-level planning documentation according to the then current theories and models for metropolitan areas.

Figure 5. Seville - Plan General de Ordenación Urbana, 1987

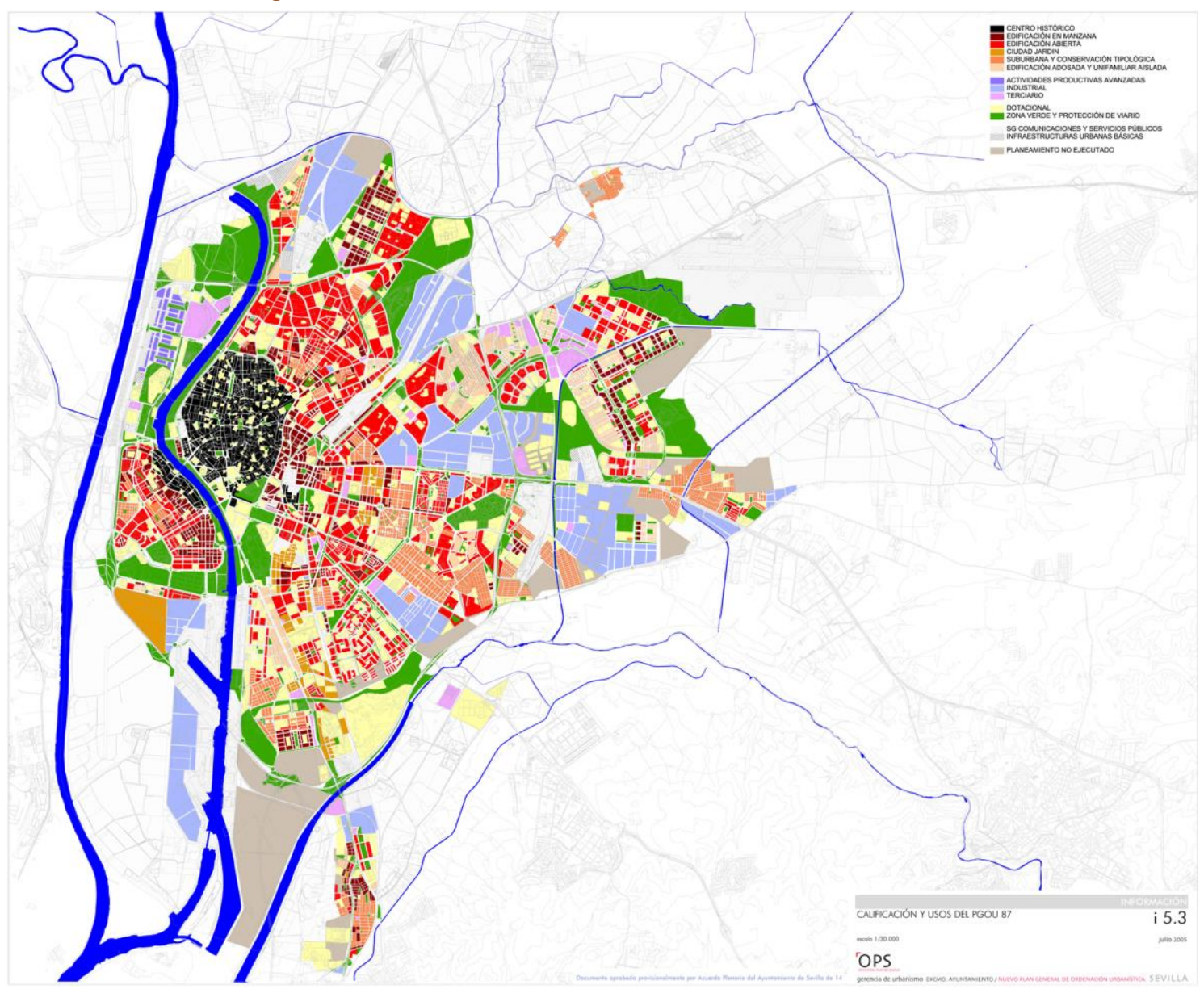

Source: Gerencia de Urbanismo - Ayuntamiento de Sevilla, 2006.

Since the period of political transition in the 1980 s and through the democratisation of the system of planning activities, the re-appraisal of the city as an uninterrupted unit was stimulated, thus negating functional zoning. A new postmodern trend was manifested in the morphological recomposition of the city realised through infill development. Influenced by the increased degree of mobility using private means of transport, the process of dispersing the urban structure continued, necessitating the revision of the Seville transport plan - Plan integral de Transporte en la Area de Sevilla. The creation of the new preparatory land-use plan, the Plan General de Ordenación Urbana (PGOU), in $1987^{15}$ (see Figure 5) overlapped with the organisation of the World EXhibition - EXPO'92. That enabled the integration of the Master Plan of the EXPO'92 site (see Figure 6) into the new PGOU of Seville. (Gerencia de Urbanismo - Ayuntamiento de Sevilla, 2006)

\footnotetext{
${ }^{15}$ The new Plan General de Ordenación Urbanistica (PGOU) of 1987 improved the balance between the centre and the periphery of the city, the general form and the recomposition of the urban tissue, and the integral protection of the historical centre. The road infrastructure network was revised based on the radial-concentric road system model, enabling better integration of the western part of the city. (Marchena Gómez, \& Hernández Martín, 2016; Petrović, 2009)
} 
Figure 6. Position of exhibition sites in urban structure of Seville

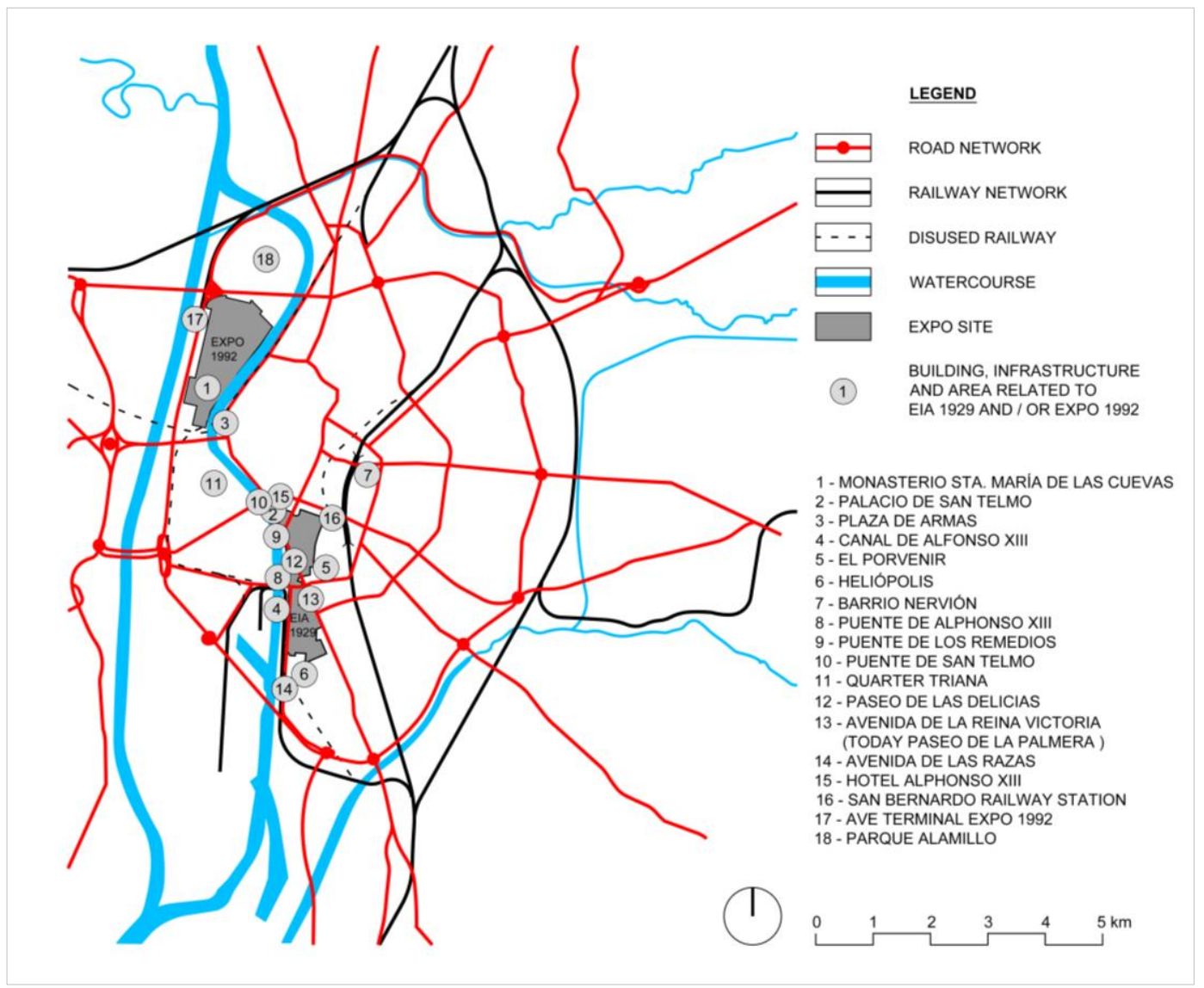

Source: Authors

\subsection{Exposición Iberoamericana 1929-1930}

At the beginning of the $20^{\text {th }}$ century, urban problems ${ }^{16}$ in Seville necessitated urgent reforms ${ }^{17}$ with the intention of modifying the urban physiognomy according to the schemes of modern urban development. Since 1908 the city authorities had planned to organise the exhibition Exposición Iberoamericana (EIA 1929) for the purpose of solving urban problems and issues with utilities in Seville, and to overcome the political, economic and social problems present throughout the country. ${ }^{18}$ The main goals of the exhibition were the revival of economic and cultural relations with former Spanish colonies, and the construction of new urban infrastructure in the context of planned urban reforms.

\footnotetext{
${ }^{16}$ In comparison with other European cities, the sanitary and technical infrastructure in Seville was at a very low level. The city government recognized the need for interventions in the city to bring it to the technical level of the 20th century. Since 1915, in conjunction with the preparations for the EIA in 1929, the city government has worked to improve the technical and social supply and make the city more beautiful. (Meyer - Künzel, 2001; Gerencia de Urbanismo Ayuntamiento de Sevilla, 2006)

${ }^{17}$ At the end of the 19th century, urban reform projects were drawn up: Proyecto de Rectificación de Calles, Apertura de una Nueva y Ensanche de Población para esta Heroica Ciudad de Sevilla, 1869 (arch. Aurelio Álvarez, Juan Francisco de Paula Álvarez); Memoria de la Inspección Sanitaria de la Compañía Acerca del Estado Higiénico de la Ciudad desde 1890 a 1902, 1890 (Dr. Laborde, Compañía Sevillana de Saneamiento y Urbanización); Proyecto General de Reformas de Sevilla, 1895 (arch. José Sáez López) etc. (Gerencia de Urbanismo - Ayuntamiento de Sevilla, 2006.)

${ }^{18}$ Although it was neutral in World War I and its economy was showing a slight increase at that time (Meyer - Künzel, 2001), Spain was going through an internal crisis, which was compounded by the loss of its last colonies in America and the emphasis on the need for the autonomy of regions within the country (Rodriguez Bernal, 1994).
} 


\section{ACE Architecture, City and Environment}

The direction of urban expansion towards the south was confirmed by urban plans from the beginning of the $20^{\text {th }}$ century ${ }^{19}$, and was additionally supported by the decision to locate the exhibition around the area of the Parque de Maria Luisa. This decision catalysed the launch of an official town planning and architectural competition for the exhibition site, in which the Spanish architect Aníbal González Álvarez-Ossorio, with his concept in the historical style, won first prize. In the 1920s the final decision was made to extend the exhibition site to the area bordered by Canal de Alfonso XIII, Avenida de la Reina Victoria (today Paseo de la Palmera), and the Guadaíra River.

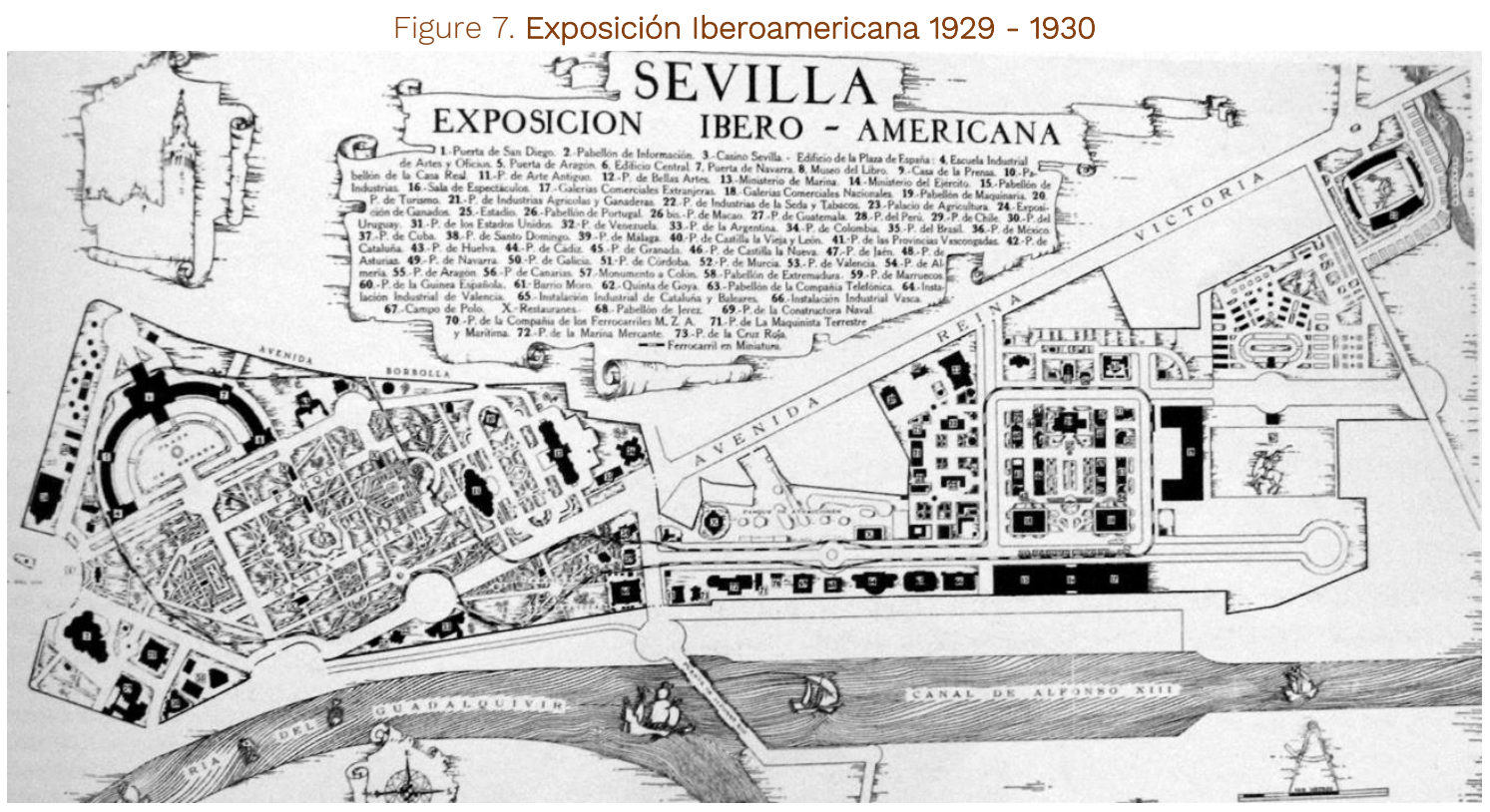

Source: Author's photo from Bureau International des Expositions Archive (B23-A1-E3-2901)

Based on this decision, the exhibition site of about 130 ha was defined and was divided by the existing infrastructure into northern and southern sectors (see Figure 7). The northern sector (Parque de María Luisa, Plaza de España, Plaza de América, and part of Jardines de las Delicias) had good connections with the old town, the railway station of San Bernardo and the newly-built luxury hotel Alphonso XIII (Exposición Ibero-Americana Sevilla 1929 - 1930, Catálogo Oficial, 1929). On the southern edge of the southern sector the Olympic stadium (arch. Antonio Illanes de Rio) and the residential quarter Heliópolis was built with 391 houses, on the principles of northern European garden cites (Gerencia de Urbanismo - Ayuntamiento de Sevilla, 2006). During the exhibition, the residential quarter was used for the accommodation of employees and visitors, and was preserved almost in its original form as part of the city's cultural heritage.

Pavilions and buildings of a permanent character built in the northern sector of the exhibition site were gradually given new functions after the closure of the exhibition. Buildings were converted into embassies and scientific institutions or were used for other public purposes retaining their original morphological characteristics. The suprastructure of the southern sector of the exhibition site was gradually changed. After the exhibition, pavilions along Avenida de las Razas were reused for industrial purposes or replaced by industrial buildings and plants. Pavilions along Avenida de Reina Mercedes

\footnotetext{
${ }^{19}$ Colonel Luis Lerdo Tejada in his text Sevilla Estación de Invierno - Plan de Reformas y Mejoras from 1900 had already mentioned Paseo de la Palmera as one of the three axes of city expansion. In 1902 architect Ricardo Velázquez Bosco drew up plans, the Proyecto de Ensanche y Urbanización de la Palmera, in which the route Paseo de las Delicias was defined as the axis of the city's expansion. In 1911 the architect Aníbal González drafted the project Proyecto de Urbanización del Cortijo Maestrescuela pointing to the favoured direction of expansion towards the south.
} 
were replaced by structures designed for residential, business or educational purposes (Colegio Mayor Hernando, Campus Universitario de Reina Mercedes). In the areas along Paseo de la Palmera, luxurious urban villas were built which have changed their purpose over time.

\title{
3.2 The World Exhibition - EXPO'92
}

At the beginning of the 1980s Andalusia was still a predominantly agricultural region with a small share of industry and services in its economy. ${ }^{20}$ Inspired by the approaching $500^{\text {th }}$ anniversary of the discovery of the Americas, in 1981 the Seville city authorities started planning and coordinating all the necessary activities related to the preparation and organisation of this large event, which was given the status of an exhibition of the first category by the Bureau International des Expositions (BIE). (Sociedad Estatal de Gestión de Activos, S.A., 1993). From the very beginning the World Exhibition EXPO'92 (EXPO 1992) was considered an accelerator of the urban and regional development of Seville. In the preparatory period of the event a new model of comprehensive urban and regional development was conceived.

In 1985 the artificial island of Cartuja was chosen for the location of EXPO 1992 (see Figure 8). The location was mostly uncultivated or flooded agricultural land and unbuilt areas, with the exception of the Monastery of Santa María de las Cuevas whose urban function had changed over the centuries (monastery, seat of a foreign army, porcelain and ceramics factory).

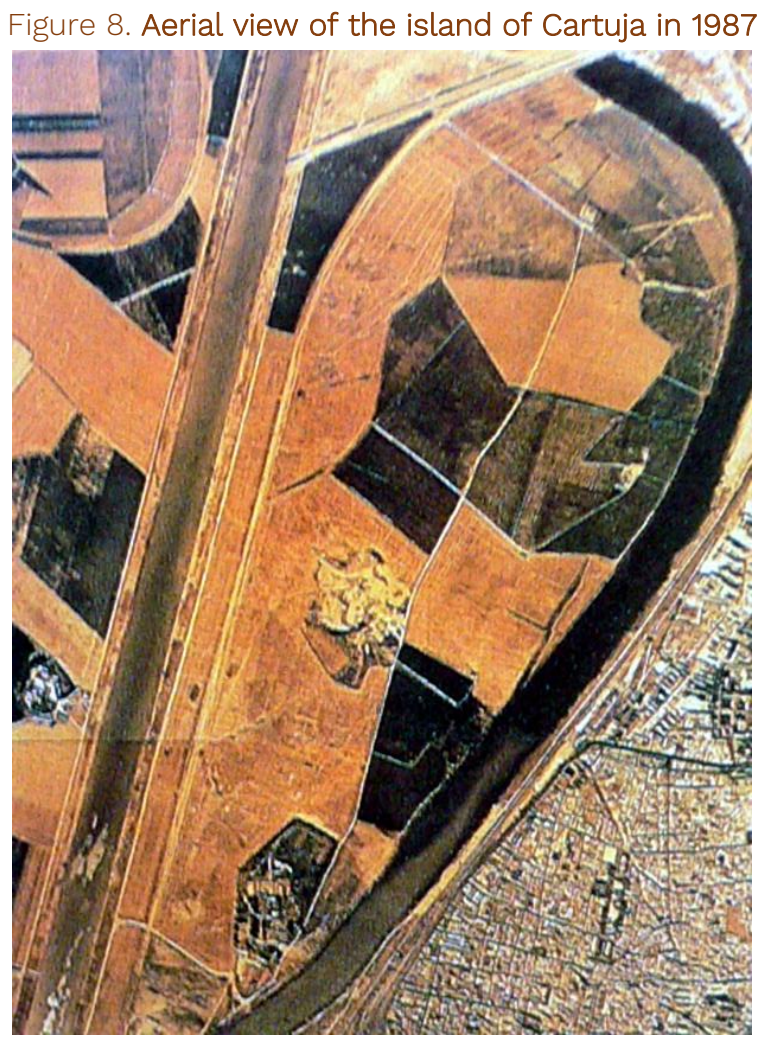

Source: Rispa, De los Rios, \& Aguaza 1992, p.17.

\begin{abstract}
20 The preparation and organisation of the EXPO 1992 stimulated activities in the city, province and region which led to the creation of new jobs, especially in the sectors of construction services and tourism. According to data from the Public Company EXPO 92 in the period from 1985 to 1993, 30,000 jobs were directly related to the large event. During the preparation of the exhibition, 200,000 new jobs (Pinot de Villechenon, 2000) were created in Andalusia which were directly and indirectly related to the event. For more details see: Petrović, 2009.
\end{abstract}

ACE, 15 (44) CC BY-ND 3.0 ES | UPC Barcelona, España | World Exhibitions and Changes in the Urban Morphology 11 of Seville. DOI: http://dx.doi.org/10.5821/ace.15.44.8762 
In 1987 the general plan, the Plan Director de la EXPO'92, for the Expo site and the development plan, Plan Especial del sector S.1 del Actur La Cartuja, including the land use of the Cartuja island in the exhibition and post-exhibition period, were adopted ${ }^{21}$.

During the exhibition, the Expo site, covering an area of 215 ha, was divided into five main zones: the zone around the Spanish Lake, the international zone, the garden zone, the monastery zone and the harbour zone (see Figure 9). Building regulations defined the position and the height of structures on the Expo site, and architects were given a free hand in architectural design. Based on the concept of subsequent use, around $30 \%$ of the pavilions were intended for long-term use for a scientific and technological park and $70 \%$ for temporary use during the exhibition.

In 1993, the city authorities adopted a development plan, the Plan Especial de Actuación Urbanística, based on which the island of Cartuja has since been used as a scientific and technological park with complementary facilities (Parque del Alamillo, the hotel sector, the theme park of the future, the university sector, the monastery complex of Santa María de las Cuevas and the administrative sector) (Sociedad Estatal de Gestión de Activos, S.A., 1993). In this way ideas for a science and technology park dating back to the 1970 s were realised.

Figure 9. Model of the EXPO'92 site on the island of Cartuja placed in Pabellón de la UE - head office of the scientific and technological park Cartuja'93

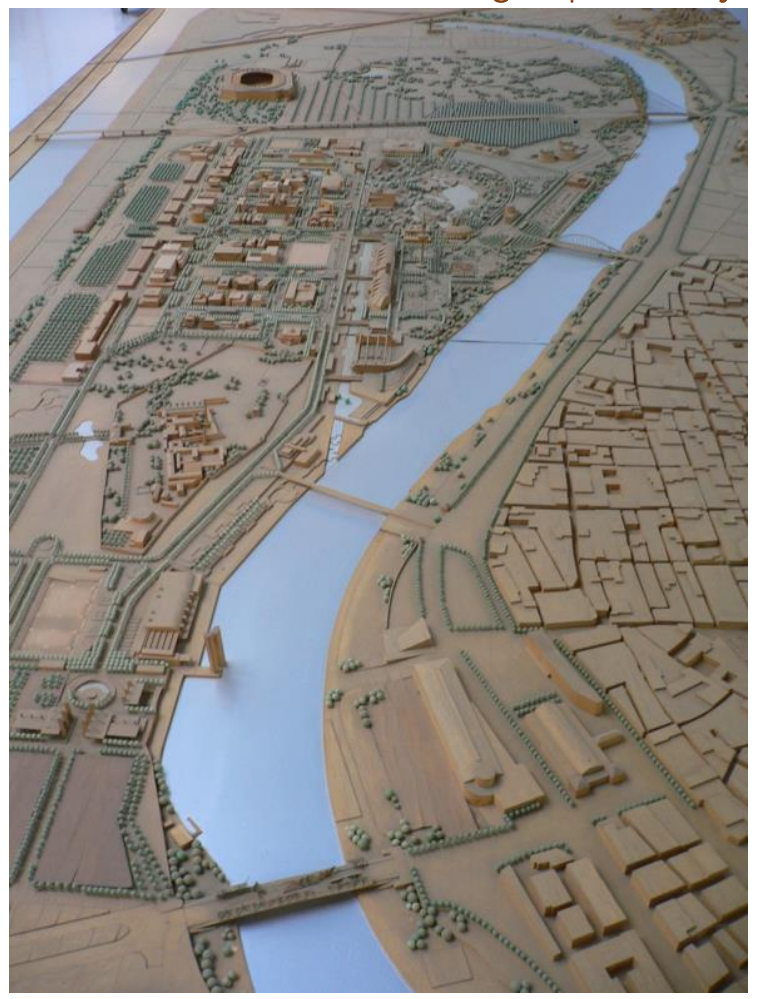

Source: Author's photo

\footnotetext{
${ }^{21}$ In 1988 an international interdisciplinary group of scientists was gathered under the leadership of Peter Hall and Manuel Castells to determine the conditions for the subsequent use of the Expo site. The group formed to carry out the project - Proyecto de Investigación sobre nuevas tecnologías en Andalucía (P.I.N.T.A.) as well as the studies for the long-term development of the area and its integration into the urban structure. Based on the analyses, the conclusion was reached that in Seville a Technopolis with a scientific and technological park should be developed with a university centre, cultural, administrative and leisure facilities. For more details see: Castells, \& Hall, 1994; Castells, \& Hall, 1990.
}

ACE, 15 (44) CC BY-ND 3.0 ES | UPC Barcelona, España | World Exhibitions and Changes in the Urban Morphology 


\section{Analysis of changes in the urban morphology of Seville}

The analysis was conducted by comparing the generative elements of urban morphology, built diachronically, at three levels of resolution since the time of their creation on the basis of the available maps of Seville and the exhibition sites. For the mathematical calculation and interpretation of changes in the urban morphology at the observed levels, graphical representations were made using AutoCAD software.

\subsection{Impact on changes in the composition of the urban structure}

The exhibition's impact on changes in Seville's urban structure was monitored by comparing the differences in the planimetric characteristics ${ }^{22}$ of the urban structure in the period before and after each exhibition. Changes were identified by analysing the compactness coefficient of the urban structure composition and the coefficient of interaction with the surroundings. ${ }^{23}$ The total built-up area of the urban structure is shown by a circle of the same area. The compactness coefficient of the urban structure composition is the ratio of the built-up area within the circle representing the area of the urban structure to the total area of the urban structure. The coefficient of interaction with the surroundings is the function of the area of an imagined circle that makes up the extent of the actual surface of the urban structure and the total area of the urban structure.

\subsubsection{Impact on changes in the composition of the urban structure}

For the assessment of changes in the composition of the urban structure, both components (north and south sectors) of the exhibition site, including the stadium and Heliópolis, were considered.

Figure 10. Diagram 4.1.1 - EIA 1929 - Changes in composition of the urban structure (4.1.1 a - urban structure before the exhibition; $4.1 .1 \mathrm{~b}$ urban structure after the exhibition)

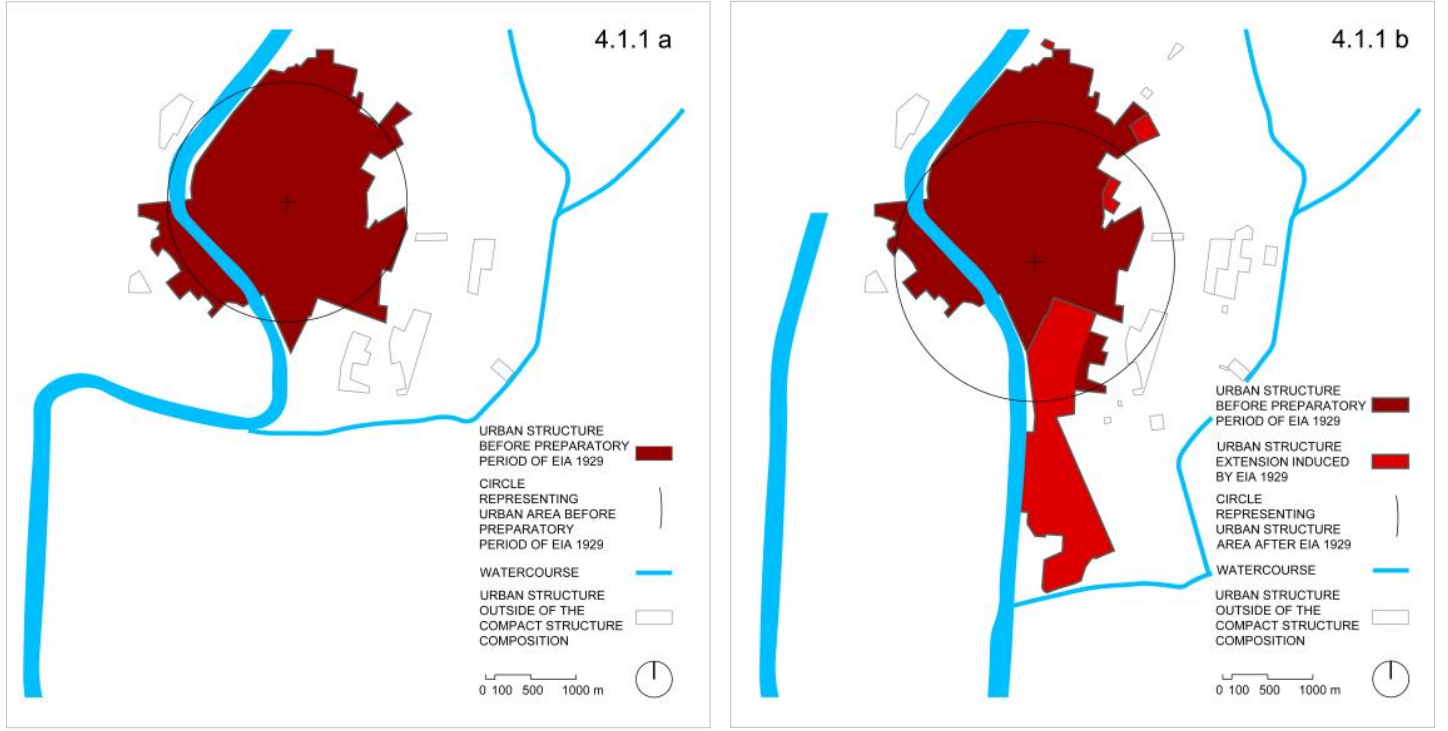

Source: Authors.

\footnotetext{
${ }^{22}$ For the purposes of this research, the surface of the continuously connected urban structure and its actual extent were analysed. These features are put in relation to the circle as an ideal form of compact structure and its expansion. Separate parts of the urban structure outside of the composition of the compact structure will be the subject of special analysis. ${ }^{23}$ The compactness coefficient and the interaction coefficient with the surroundings are calculated based on the relations of the features of the planimetric characteristics of the urban structure and the imaginary circles of the same quantitative features (surface and perimeter).
}

ACE, 15 (44) CC BY-ND 3.0 ES | UPC Barcelona, España | World Exhibitions and Changes in the Urban Morphology 13 of Seville. DOI: http://dx.doi.org/10.5821/ace.15.44.8762 
From Figure 10 - Diagram 4.1.1 b it can be seen that in the period immediately after the EIA 1929, as a result of the interventions carried out on the occasion of the exhibition, the built-up area of the city increased by 201 ha or $36.19 \%$, and that Seville's urban structure compactness coefficient was reduced to a smaller extent (21.06 \%). The compactness coefficient increased considerably in the post-exhibition period due to the construction of the eastern and southern parts of Seville, boosted by infrastructure built in the pre-exhibition period (EXPO Reverse Effect). The perimeter of the built area increased by $53.88 \%$, and the interaction coefficient with the surrounding area increased by $77.25 \%$.

\subsubsection{EXPO 1992 - Changes in the composition of the urban structure}

Interventions in the infrastructure of Seville's urban tissue, and the construction of the exhibition site and the northern and southern part of the island of Cartuja, brought about by the organisation of EXPO 1992, fill the gaps of the north-western part of the city structure. The construction of the eastern part of the urban fabric also made it possible to integrate previously constructed parts of the urban structure into a compact composition.

The implemented interventions in the preparatory period of the event and the integration of the "islands" of existing construction increased the area of the urban structure by $40.79 \%$. The existing city structure area of 4,716 ha was increased by 1,924 ha (of which 215 ha comprises an exhibition site on the island of Cartuja).

Figure 11. Diagram 4.1.2 - EXPO 1992 - Changes in composition of the urban structure (4.1.2 a urban structure before the exhibition; $4.1 .2 \mathrm{~b}$ - urban structure after the exhibition)
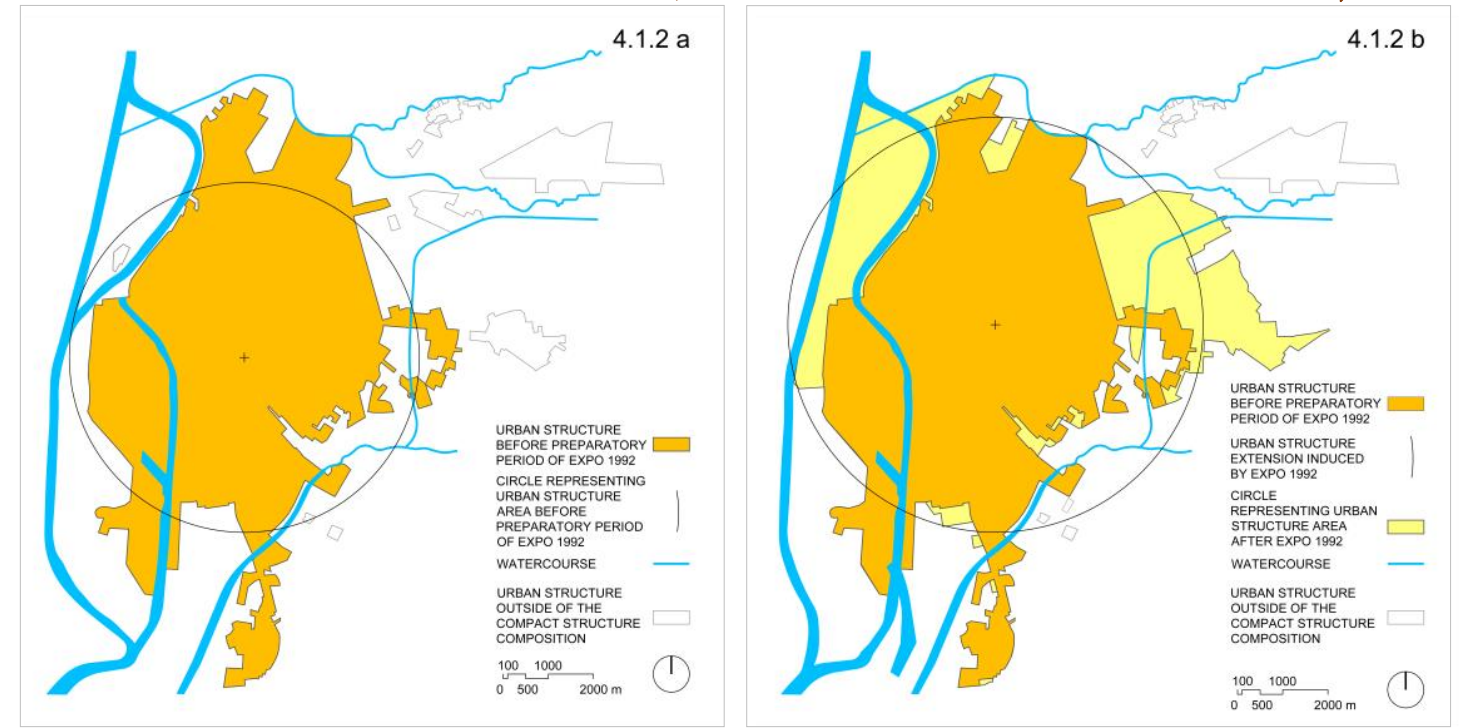

Source: Authors.

From Figure 11 - Diagram 4.1.2 b it is clear that the infrastructure, suprastructure and ecostructures built on the island of Cartuja on the occasion of EXPO 1992 affected the compactness of the city structure, as well as the construction of new and the integration of previously constructed isolated parts of the urban structure in the eastern part of the city. The compactness coefficient was increased from 0.78 to 0.83 (5.60\%), but simultaneously the interaction coefficient with the surroundings was reduced by $22 \%$. The perimeter of the built area was increased by approximately $5 \%$.

ACE, 15 (44) CC BY-ND 3.0 ES | UPC Barcelona, España | World Exhibitions and Changes in the Urban Morphology of Seville. DOI: http://dx.doi.org/10.5821/ace.15.44.8762 


\subsection{Constructive elements of urban tissue}

A large number of different features at this level of resolution represent a challenge to an analysis of urban morphology due to the intrarelational, interrelational and extrarelational activities of many component elements and their effect on the diversity of urban tissue.

Considered chronologically, the emergence of constructive elements as parts of the urban tissue ${ }^{24}$, and their functional use, determine the criteria for morphological analysis at this resolution level.

At this level the routes of roads and other infrastructure determine the form of the planimetric characteristics of urban structure components. They form the boundaries between the components of the urban structure composition and connect two or more formative points, and in these considerations, we give them a name - the cardinal routes of the road (and other) infrastructure. Nevertheless, on the formation of urban tissue textures, the collecting roads, which are in principle connected perpendicular to the primary roads, have the most influence within a particular component of the urban structure, and by means of the connectors provide access to each plot and buildings.

The main feature of the urban tissue texture is not only the diversity of buildings whose coexistence stems from common formative and/or transformative processes. An important feature of the urban tissue texture is made up of well-designed, unbuilt and open spaces of various types, forms and functions such as squares, streets, avenues, boulevards, walking trails, promenades and parks, and sports and recreational areas and playgrounds. At this resolution level, a representative sample of an urban tissue component is selected within which the network of transport infrastructure with its characteristics ${ }^{25}$ and features of the representative sample of urban tissue texture are analysed.

\subsubsection{EXPO 1992 - Changes in the composition of the urban structure}

The northern sector of the exhibition site (Parque de Maria Luisa) with buildings and infrastructure of a permanent character represents, typologically and chronologically, a unique morphological framework with a clear boundary of urban tissue. In the formative sense, the texture of this urban tissue component is divided by the streets Paseo de las Delicias and Av. de María Luisa into three areas with the same typological characteristics but containing different morphological features.

Two different types of the same morphological pattern were identified in the eastern part of the urban tissue component. In the southern part of the zone, a rectangular square, Plaza de América, is bordered on three sides by pavilion-type public buildings (Pabellón de la Casa Real - today's city office; Pabellón de Arte Antiguo and Pabellón Mudéjar - today Museo de Artes y Costumbres Populares; Pabellón de Bellas Artes - today Museo Arqueológico), and at the southern edge the pavilions Pabellón del Brasil (today Universidad de Sevilla: Centro de Formación Permanente) and Pabellón de México (now the Universidad de Sevilla: Escuela International de Doctorado). In the northern part of the zone, the semi-elliptical square Plaza de España is formed, bordered by a oneto three-storey semi-elliptical building along one entire half of the ellipse envelope. During the exhibition, the building was an exhibition space for Escuela Industrial de Artes y Oficios, Puerta de Aragón, Edificio Central, Puerta Navarra and Museo del libro. Today, this building is the headquarters

\footnotetext{
${ }^{24}$ Built and unbuilt parts of the urban tissue texture intertwined with the infrastructure and ecostructure networks are constructive elements which form the urban structure component.

${ }^{25}$ The hierarchical road structure and visibility are analysed on the selected representative sample. Visibility is calculated by the coefficient of visibility, which is expressed by the ratio of the length as a straight line connecting two points in space and the actual length of the road (corrected by the function of the sine and cosine tangents of the curved sections of the roads). On the representative sample the features of urban tissue textures are analysed using building coverage coefficients, plots open space coefficient, ratio of plots and green areas to total observed area, ratio of roads to total observed area, and relationships of the transport network hierarchy.
} 
of public and social, as well as business facilities. In the centre of the zone is Parque de Maria Luisa with its irregular pentagonal shape, with two parallel sides that determine the direction of the main paths - two ordinates and one abscissa that links the gravity centre of Plaza de España and the crossing of Avenida de María Luisa and Paseo de las Delicias. The areas between the peripheral streets and the main thoroughfares are fragmented by various forms of links in all directions, giving eclectic features to the park composition. In the south-western part of the component, on a triangular-shaped area (separated from Parque de María Luisa) there were pavilions (Pab. de Columbia, Pab. de Marruecos, Pab. de la Guinea Español, Pab. de la Argentina, Pab. de Venezuela and Pab. de Guatemala) which have remained a lasting legacy. In the north-western part of this urban tissue texture component, Casino / Teatro Lope de Vega and the pavilions of Chile, Uruguay, Peru and the United States were built, and were turned into embassies or accommodation for other public facilities.

For the analysis of the transport infrastructure of the urban tissue, the entire northern sector of the exhibition site was taken into the consideration. The area is linked with the wider city area by the south-eastwards headed main radial road, once Av. Reina Victoria, today Paseo da las Delicias and Av. de la Palmera, and Av. de María Luisa, oriented to the south-west.

Figure 12. Diagram 4.2.1 a - EIA 1929 - transport infrastructure

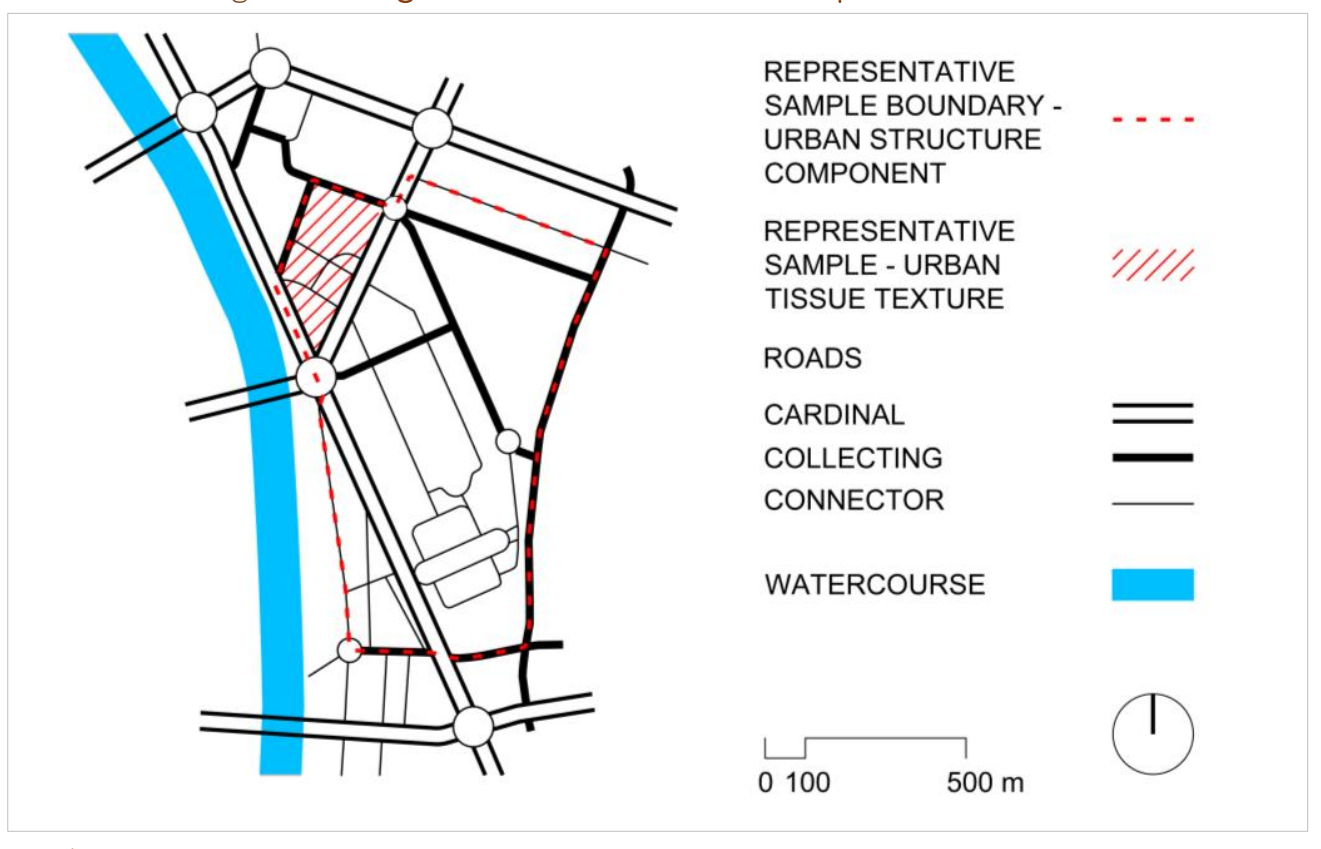

Source: Authors.

From Figure 12 - Diagram 4.2.1 a, it is apparent that the axes of these roads have straighteners / rectilinear characteristics (with the exception of $A v$. de Borbolla) which ensure good visibility and movement through the urban tissue. The total area of the sample at this resolution level is 65.60 ha and the total length of the roads is $10.660 \mathrm{~m}$ or $162 \mathrm{~m} / \mathrm{ha}(24 \mathrm{~m} /$ ha cardinal, $56 \mathrm{~m} / \mathrm{ha}$ collecting and $82 \mathrm{~m} /$ ha connecting roads).

To calculate the quantitative and qualitative indicators of the urban tissue texture elements, a northwestern street block of the northern sector of the urban tissue component was selected as a representative sample. The street block selected as a representative sample for the analysis of built and unbuilt areas of urban tissue texture has a total area of $7.28 \mathrm{ha}$, bordered by the Paseo de las Delicias $(\mathrm{w}=34 \mathrm{~m})$, Av. de María Luisa $(\mathrm{w}=28 \mathrm{~m})$, Calle Palos de la Frontera $(\mathrm{w}=28 \mathrm{~m})$ and La Rábida $(\mathrm{w}=20 \mathrm{~m})$. (See Figure 13 - Diagram $4.2 .1 \mathrm{~b})$. 
By comparing the planimetric characteristics of the aforementioned constructive elements of the texture, the average building coverage for the EIA 1929 urban tissue is $27 \%$, or $16 \%$ of the total area of the representative sample. Open spaces comprise $73 \%$ of the total building plots. Of the total area of the representative sample, open spaces of the plots and public greenery amount to $57 \%$, of which $14 \%$ belong to public open spaces and $43 \%$ to building plots.

The forms of the plots and access to buildings are subordinate to the hierarchy and direction of the roads, so the heterogeneity of the plots reflects the fragmentation and heterogeneity of the planimetric characteristics of the buildings. The building lines are aligned with the road directions with the exception of the Teatro Lope de Vega building, which with its composition and longer axis is subject to the baroque concept of the park and does not respect the directions of the streets in the environs of its plot.

Figure 13. Diagram 4.2.1 b - EIA 1929 - Built and unbuilt areas - sample of urban tissue texture

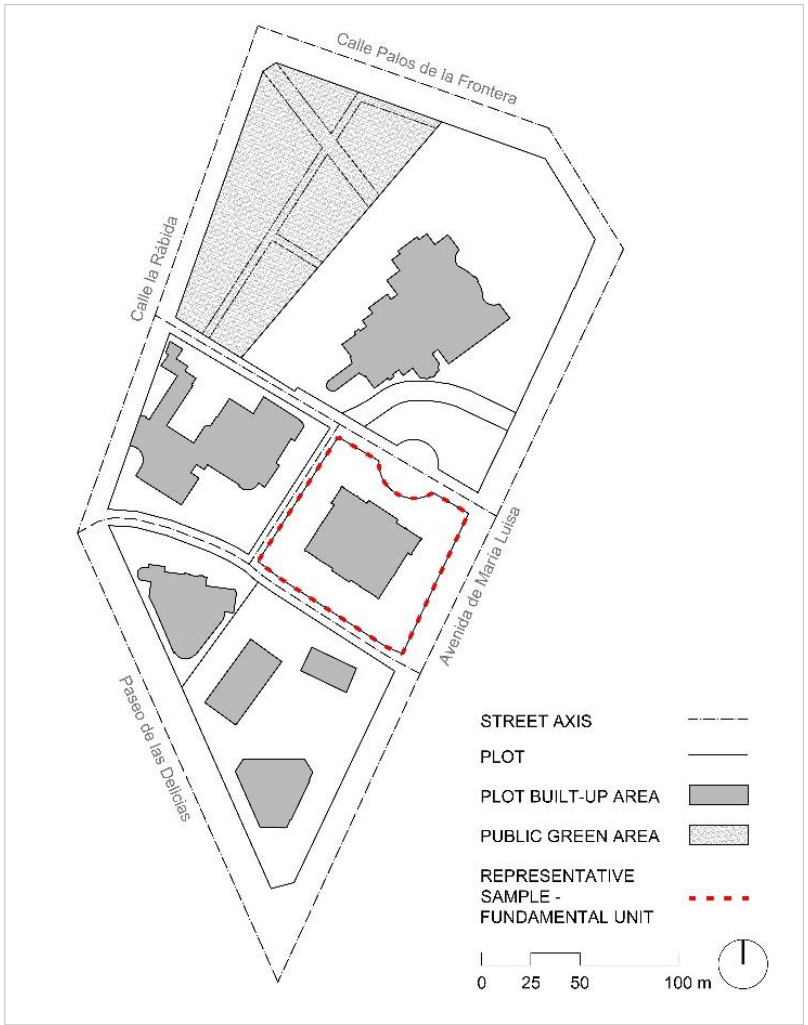

Source: Authors

\subsubsection{EXPO 1992 - Constructive elements of the urban tissue}

As a criterion for determining the morphological framework of constructive elements - the second level of resolution of urban morphology, the area bordered by the cardinal roads of the city's urban structure was taken into consideration. In this case, they are: Viaducto del Alamillo, Av. de Carlos III, Av. del Odiel and the canal Meandro de San Jerónimo, parallel to Calle Torneo.

This morphological framework encompasses the exhibition site zones of various uses: the Parque de los Descubrimientos, the amusement park Isla Mágica, an auditorium with the park Jardín del Guadalquivir, the historic area Monasterio de Sta. María de las Cuevas and in the south an administrative and commercial zone. All zones are characterised by specific morphological patterns of urban tissue texture that make up the urban structure components.

ACE, 15 (4.4) CC BY-ND 3.0 ES | UPC Barcelona, España | World Exhibitions and Changes in the Urban Morphology 17 of Seville. DOI: http://dx.doi.org/10.5821/ace.15.44.8762 
From Figure 14 - Diagram 4.2.2 a, it is obvious that the cardinal roads of the EXPO 1992 site provide good direct connections with the medieval city centre and its regional surroundings. The area of the observed sample at this resolution level is 184.4 ha and the total length of the roads is $19.194 \mathrm{~m}$ or $104 \mathrm{~m} / \mathrm{ha}$ (of which cardinal roads are $15 \mathrm{~m} / \mathrm{ha}$, collecting roads $35 \mathrm{~m} / \mathrm{ha}$, and connector roads 54 $\mathrm{m} / \mathrm{ha})$.

On the site there are good higher and middle level road connections along the artery Av. de Carlos III. The visibility of movement at the level of collecting roads within Parque de los Descubrimientos and the auditorium is at a high level. On Isla Mágica it is at a somewhat lower level, and in the administrative and commercial area the connection is absent or has merged with the third level of the roads, i.e. connectors. The connecting roads in all five zones of the urban tissue of the site provide good connections between plots and buildings and higher-level roads within the site. The exhibition site is linked by a railway and AVE terminal to the railway network connecting Seville and Madrid, while a heliport located between the exhibition zone and the commercial and administrative zone provides connectivity with air traffic. Pedestrian bridges linking the complex Monasterio de Sta. María de las Cuevas and Isla Mágica with the historic city core increase the degree of urbanisation of the area of the subject component.

\section{Figure 14. Diagram 4.2.2 a - EXPO 1992 - transport infrastructure}

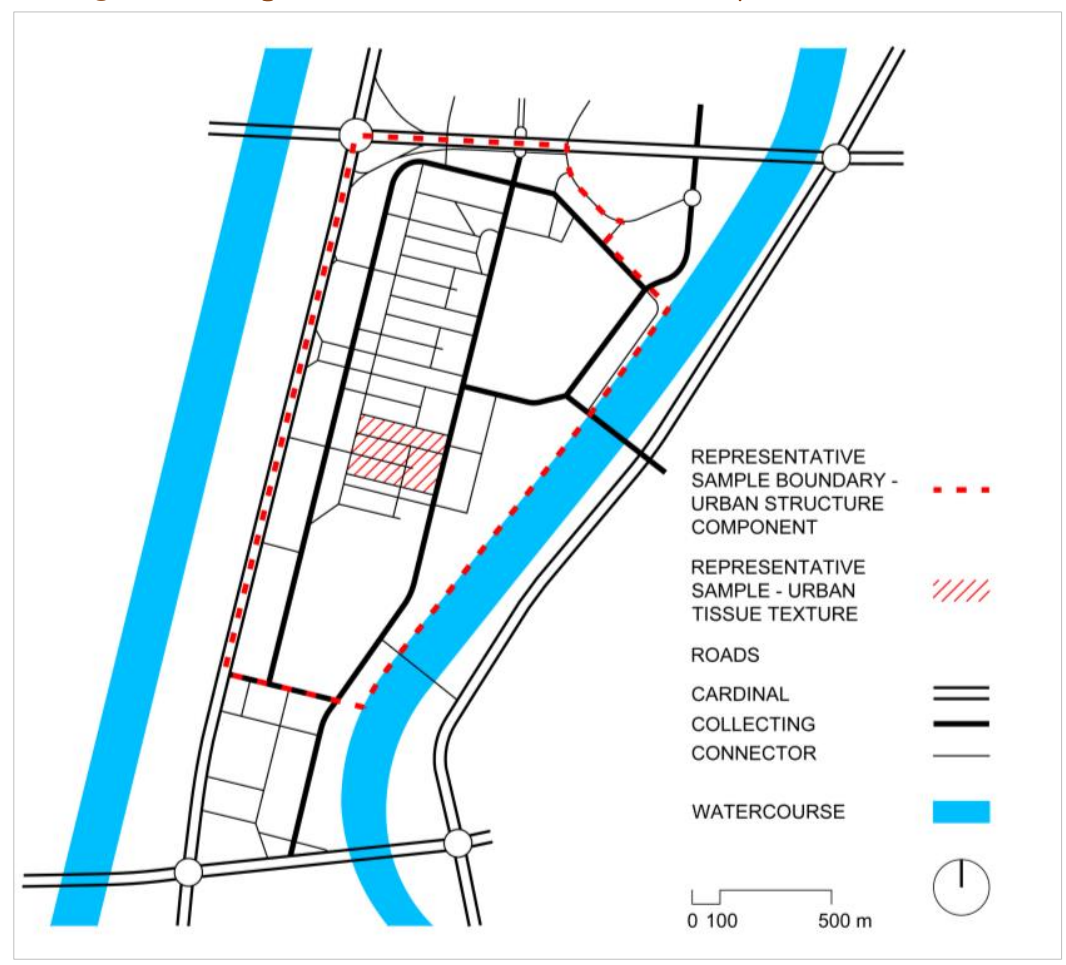

Source: Authors.

Each of the five zones of the components of the urban tissue represents a specific pattern derived from the different functions and types of urban fabrics and the rules of their creation and organisation. All five morphological zones have in common built areas which are separated from the marginal roads by water surfaces or public green areas. The relation between built and unbuilt areas, in all zones, shows a high degree of urbanity. Even the names of the parts of the zones or the zones themselves point to the relationship between the built and unbuilt areas of the urban tissue texture. The central area of the exhibition site, Parque de los Descubrimientos, consists of four clusters of the same typological characteristics. 
For the calculation of the quantitative and qualitative indicators of the urban tissue textures as a representative sample the southern cluster was selected, consisting of three street blocks. The urban tissue subject sample is bordered by the streets Calle Albert Einstein, Camino de los Descubrimientos, both collecting roads, and Calle Charles Darwin and Calle Leonardo da Vinci, both connector roads, while Calle Gregor J. Mendel has a connector supply function.

From Figure 15 - Diagram 4.2.2 b it can be determined that the representative sample of the urban tissue texture of the central zone of the exhibition site is $330 \times 220 \mathrm{~m}$ or 7.26 ha, of which the traffic infrastructure comprises $20 \%$ (total length $1.714 \mathrm{~m} ; 236 \mathrm{~m} / \mathrm{ha}$ ), building plots $38 \%$ and public greenery $42 \%$ of the total area of the representative sample. In the traffic infrastructure areas (20\%), the share of the collecting roads is $4.5 \%$ and connector roads $15.5 \%$.

Figure 15. Diagram 4.2.2 b - EXPO 1992 - sample of urban tissue texture - built and unbuilt areas

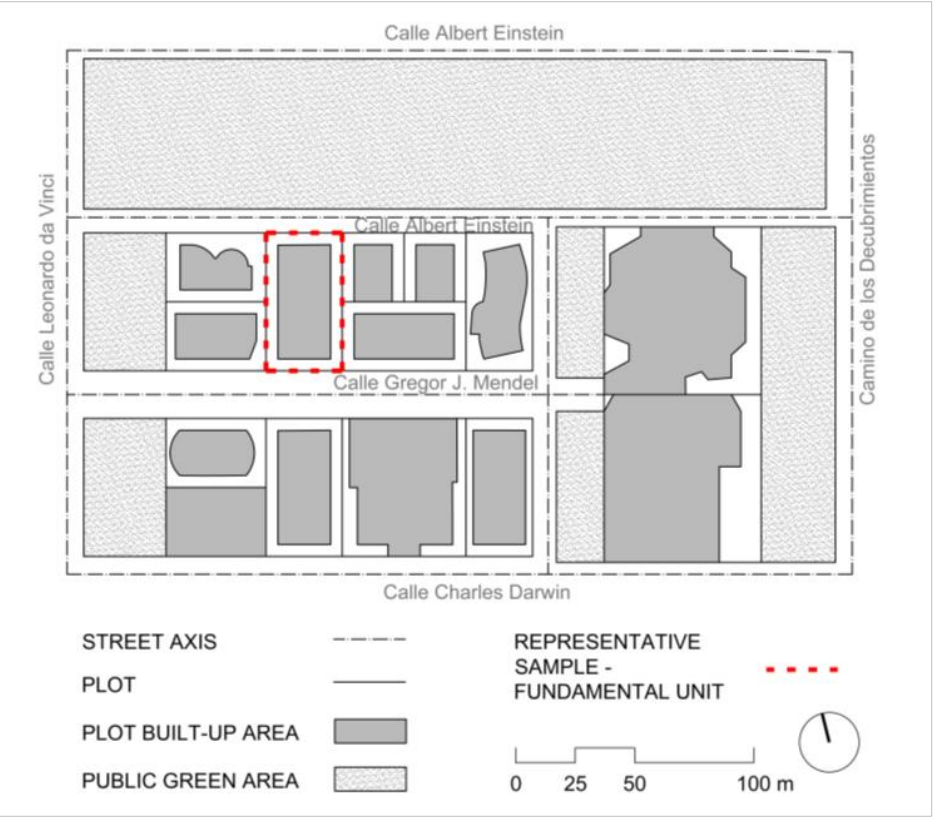

Source: Authors

The average building coverage (planimetric indicators) is $66 \%$, i.e. $25 \%$ of the total area of the representative sample, and plot open space is $34 \%$. Out of the total area of the site (72,600 m2), 55 $\%$ comprises unbuilt areas (open public areas and unbuilt areas of plots), of which $42 \%$ belong to public use and $13 \%$ belong to building plots.

The street blocks of the observed sample are orthomorphic and heterometric, sizes of $68 \times 192 \mathrm{~m}$ and $116 \times 140 \mathrm{~m}$ divisible into smaller modular plots in multiples of $4 \mathrm{~m}$, with the possibility of a twosided approach to buildings (for pedestrians and deliveries). The building lines on the collecting road side are $32 \mathrm{~m}$ away from the edge of the road, and $5 \mathrm{~m}$ from the connecting road on the longer sides of the street block. Buildings constructed in street blocks measuring $116 \times 140 \mathrm{~m}$ are $32 \mathrm{~m}$ away from the collecting roads, $4 \mathrm{~m}$ from pedestrian connectors and $20 \mathrm{~m}$ from supply connectors.

The shapes of the plots and buildings come from a clearly defined orthomorphic concept of this morphological zone in which the building lines and the alignment of buildings and streets dominate the hierarchy of importance of the generative elements at this level of resolution.

ACE, 15 (44) CC BY-ND 3.0 ES | UPC Barcelona, España | World Exhibitions and Changes in the Urban Morphology of Seville. DOI: http://dx.doi.org/10.5821/ace.15.44.8762 
In addition to green areas of the plot, plans have been anticipated and realised for public open spaces $64 \mathrm{~m}$ wide and $316 \mathrm{~m}$ long enclosed on two sides by pedestrian connectors. Unbuilt open spaces are equipped with urban equipment suitable for relaxation and spending time outdoors.

The division of the street block on the longer side allows for direct contact of the street (pedestrian and supply connector) and the plot. If we assume that the ratio of the plot width and the depth of the building plot is a maximum of 1:2, then the minimum width of the plot is greater than or equal to $32 \mathrm{~m}$. An example of such a plot is considered at the next level of resolution (Section 4.3.2).

\subsection{Generative elements of the basic morphological unit}

This level of analysis, generation of urban fabrics, represents a fundamental level of resolution of urban morphology. It embodies a morphological concept ${ }^{26}$ and gives identity to the city. The generative elements of the fundamental morphological units at this level of resolution are streets, plots, buildings and open spaces. Their shapes, interrelations and rules create different patterns of urban tissue texture.

For the purposes of this resolution level, a representative sample of a fundamental morphological unit was selected. The relationships between the generative elements were analysed by calculating the coefficients ${ }^{27}$ within the relationship matrix (Levy, 1999; Oliveira, 2013). The relationship matrices are composed of three areas of relation: the area of unit values (diagonal), the areas of direct relationships and the areas of inverse relationships.

\subsubsection{ElA 1929 - Representative sample of fundamental morphological units}

For the analysis of the urban tissue texture of EIA 1929, as a representative sample, a street block was selected in the north-west part of the site, which is bordered by Av. de Maria Luisa and Av. del Perú. From this street block, the pavilion Pabellón del Perú was taken to analyse the morphological characteristics at this level, as it has retained its original form still today (Figure 16 - Diagram 4.3.1).

The representative unit plot, the size of which is $0.64 \mathrm{ha}$, is almost orthogonal and is surrounded by streets on all sides. The building is accessed from the connecting road Av. de Perú, which is $12 \mathrm{~m}$ wide. The building is of the pavilion type, and is centrally positioned on a plot with the dimensions 50 $\times 40 \mathrm{~m}$ and is removed from the aforementioned connecting road by $22 \mathrm{~m}$.

From the plot area, the relationships between the building width and the plot width $(3 / 1=0.55)$, the width of the open space in front of the building and the width of the street $(4 / 1=1.83)$ and the open area of the plot and the built-up area of the plot $(4 / 3=2.52)$, it is obvious that the observed unit shows the characteristics of pavilion construction appropriate to new tendencies in urban planning of the first half of the $20^{\text {th }}$ century.

\footnotetext{
${ }^{26}$ Analysis of a morphological concept is entirely in accordance with the Conzenian criteria (Whitehand, 2001).

${ }^{27}$ The following indicators were selected for the purposes of this resolution level: accessibility coefficient (ratio between plot width and street length in front of the parcel), ratio between building width and plot width, ratio between plot builtup area and plot area, ratio of distance between property and build-to line and street width, ratio between plot open space and plot area, and ratio between plot open space and plot built-up area.
} 
Figure 16. Diagram 4.3.1 - EIA 1929 - The relationship matrix of the generative elements of the urban fabrics of the representative sample

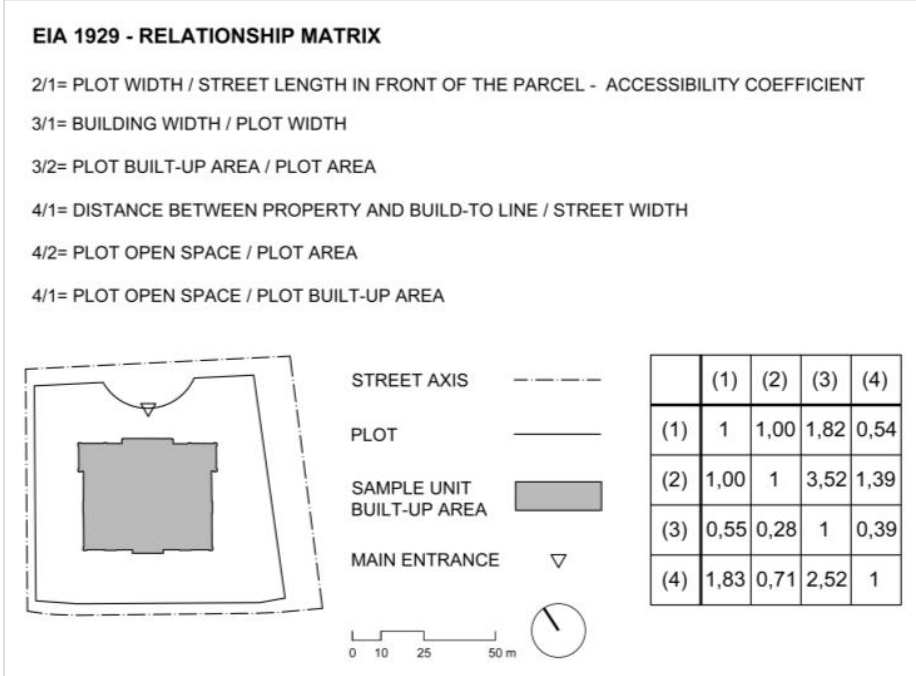

Source: Authors

\subsubsection{EXPO 1992 - Representative sample of fundamental morphological units}

For the calculation of the quantitative and qualitative indicators of the elements of the fundamental morphological units, a plot of the southern street block of the subject component of urban tissue texture (see Figure 17 - Diagram 4.3.2) of a proper orthogonal shape, $32 \mathrm{~m}$ wide and $58 \mathrm{~m}$ depth (1,856 $\mathrm{m} 2$ ) was chosen as a representative sample. The plot is bordered on the northern side by the vehicle and pedestrian connecting road Calle Albert Einstein, $6 \mathrm{~m}$ wide, on the southern side by Calle Gregor $\mathrm{J}$. Mendel, $10 \mathrm{~m}$ wide, and at each side by adjacent plots of the same street block. The building of the representative sample is $5 \mathrm{~m}$ away from all plot boundaries.

Figure 17. Diagram 4.3.2 - EXPO 1992 - The relationship matrix of the generative elements of the urban fabrics of the representative sample

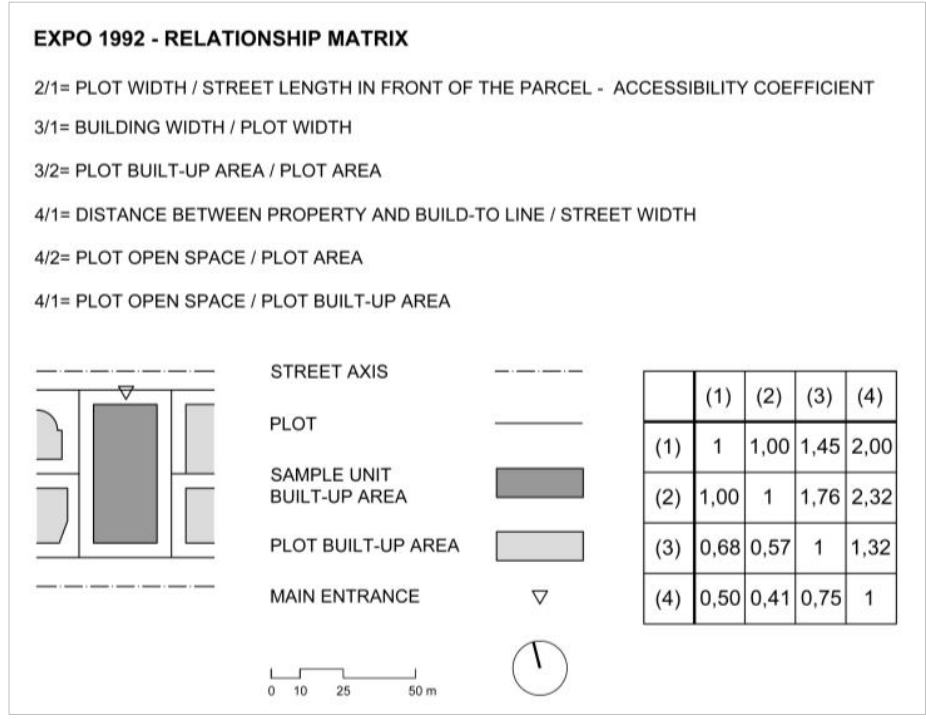

Source: Authors

ACE, 15 (4.4) CC BY-ND 3.0 ES | UPC Barcelona, España | World Exhibitions and Changes in the Urban Morphology of Seville. DOI: http://dx.doi.org/10.5821/ace.15.44.8762 
The relationship coefficient matrix of the generative elements of the representative fundamental morphological unit shows the rational use of the plot area $(3 / 2=0.57)$ and the immediate access to the building from the street, i.e. vehicular and pedestrian access $(4 / 1=0.50)$. The small share of the open space of the plot area $(4 / 2=0.43)$ refers to plots within a street block. The edge plots of the street block have a much more favourable relationship thanks to public open spaces.

\subsection{A comparative analysis of diachronic changes in quantitative indicators of urban morphology}

For a comparative overview of changes in the quantitative indicators of Seville's urban morphology a total of 24 indicators at three levels of resolution were compared. The following results were obtained by the comparison method of the effect of spatial interventions.

At level 4.1 the indicators of the effect of the intervention on the urban structure composition, presented through the coefficients of compactness and interaction with the environment, show an inverse relationship. For EIA 1929, a reduction in the compactness coefficient results in an increase in the coefficient of interaction with the environment (0.7893/1.7725), and for EXPO 1992, an increase in the compactness coefficient results in a decrease in the interaction coefficient with the environment (1.0560/0.7800).

Table 1. Comparative analysis of quantitative indicators

\begin{tabular}{|c|c|c|}
\hline & EIA 1929 & EXPO 1992 \\
\hline LEVEL 4.1 - COMPOSITION OF THE URBAN STRUCTURE & 4.1.1 & 4.1 .2 \\
\hline INCREASE IN BUILT AREA & 1.3619 & 1.4079 \\
\hline COMPACTNESS COEFFICIENT & 0.7893 & 1.0560 \\
\hline INTERACTION COEFFICIENT WITH THE SURROUNDING AREA & 1.7725 & 0.7800 \\
\hline $\begin{array}{l}\text { RATIO OF THE BUILT AREA PERIMETER AFTER EXHIBITION TO THE BUILT AREA } \\
\text { PERIMETER BEFORE EXHIBITION }\end{array}$ & 1.5388 & 1.0509 \\
\hline LEVEL 4.2 A - COMPONENT OF THE URBAN STRUCTURE & $4.2 .1 \mathrm{a}$ & $4.2 .2 \mathrm{a}$ \\
\hline SUBJECT INTERVENTION AREA (ha) & 65.60 & 184.40 \\
\hline ROADS (m/ha) & 162 & 104 \\
\hline - $\quad$ CARDINAL & 24 & 15 \\
\hline - $\quad$ COLLECTING & 56 & 35 \\
\hline - $\quad$ CONNECTOR & 82 & 54 \\
\hline VISIBILITY COEFFICIENT OF CARDINAL AND COLLECTING ROADS & $\approx 1.00$ & $\approx 1.00$ \\
\hline LEVEL 4.2 B - REPRESENTATIVE SAMPLE OF URBAN TISSUE & $4.2 .1 \mathrm{~b}$ & $4.2 .2 \mathrm{~b}$ \\
\hline REPRESENTATIVE SAMPLE AREA (ha) & 7.28 & 7.26 \\
\hline BUILDING COVERAGE COEFFICIENT & 0.27 & 0.66 \\
\hline PLOTS OPEN SPACE COEFFICIENT & 0.73 & 0.34 \\
\hline RATIO OF GREEN AND UNBUILT / OPEN SPACES TO TOTAL OBSERVED AREA & 0.57 & 0.55 \\
\hline RATIO OF PLOTS AREA AND GREEN AREAS TO TOTAL OBSERVED AREA & 0.73 & 0.80 \\
\hline RATIO OF ROADS TO TOTAL OBSERVED AREA & 0.27 & 0.20 \\
\hline ROADS (m/ha) & 214 & 236 \\
\hline - $\quad$ CARDINAL & 34 & - \\
\hline - $\quad$ COLLECTING & 122 & 60 \\
\hline - $\quad$ CONNECTOR & 58 & 175 \\
\hline LEVEL 4.3 - FUNDAMENTAL MORPHOLOGICAL UNIT & 4.3.1 & 4.3 .2 \\
\hline \multicolumn{3}{|l|}{ THE RELATIONSHIP MATRIX } \\
\hline 1/3 PLOT WIDTH /BUILDING WIDTH & 1.82 & 1.45 \\
\hline 3/2 BUILDING COVERAGE COEFFICIENT & 0.28 & 0.57 \\
\hline 4/1 DISTANCE BETWEEN PROPERTY AND BUILD-TO LINE / STREET WIDHT & 1.83 & 0.50 \\
\hline 4/2 PLOT OPEN SPACE COEFFICIENT & 0.72 & 0.43 \\
\hline
\end{tabular}

Source: Authors.

ACE, 15 (44) CC BY-ND 3.0 ES | UPC Barcelona, España | World Exhibitions and Changes in the Urban Morphology 
An analysis of the transport infrastructure of the urban tissue texture at the second level of resolution (4.2 A) indicates a discrepancy between the expected and obtained research results. There is a significantly higher share of roads at the EIA 1929 site (162 m/ha) compared to the EXPO 1992 site (104 $\mathrm{m} / \mathrm{ha}$ ). In the first instance it is a consequence of the function of third level roads (vehicular and pedestrian service routes), and in the second case a smaller share of the roads on the site is a consequence of the absence of cardinal roads from the representative sample and the concept of gathering building plots in clusters / street blocks. From the analysis of the constructive elements of the urban tissue texture at the second level of resolution (4.2.B) it follows that at the level of the representative sample, a significant difference in the building coverage (0.27/0.66) or plot open space $(0.73 / 0.34)$ is the result of the typological and functional difference in the post-exhibition period of urban construction. The share of green and unbuilt / open spaces in the total observed area of the sample is approximately the same (0.57/0.55). In the first example, it is a consequence of the distinguished character function of urban construction, and in the second example it is a consequence of the urban concept. In the first case, the share of roads $(0.27 / 0.20)$ is higher due to the proximity of the city centre and due to the greater linkage to the radially concentric and orthogonal concept of higher-level traffic infrastructure and the absence of cardinal roads in traffic infrastructure in the second example.

At the third level of resolution (4.3) representative samples of the fundamental morphological unit, diachronically speaking, the most noticeable differences in the changes of the generative elements are visible. The difference in the building coverage $(0.28 / 0.57)$ is more than double, and the difference between the open space of plots $(0.72 / 0.43)$ is significant, which is the result of different typological characteristics of urban constructions. Formative processes, as a result of function and time, are manifested in different characteristics of streets, plots, buildings and open spaces. The streets in both examples have common features, and the plots and buildings differ. In the example of EIA 1929, the plots are heteromorphic and heterometric, and for EXPO 1992 they are orthogonal and heterometric. Buildings are in both cases heteromorphic. The relationship coefficients between the width of the open space in front of the building and the width of the street show the greatest divergence. In the EIA 1929 example the coefficient is 1.83, and for EXPO 1992 it is 0.50. In the first example, it is the consequence of the distinguished character of the morphological unit function, and in the second example it is the consequence of the rationality of modern urbanism.

\section{Conclusions}

For this research on changes in urban morphology, Seville was chosen as an example of a mediumsized city whose two exhibitions, Exposición Iberoamericana 1929-1930 and the World Exhibition EXPO'92, served as a means of achieving planned urban reforms (transformative processes) and overall city development.

From the analysis of the changes in the urban morphology of Seville brought about by the organisation of the exhibitions, it can be concluded that they are an appropriate means for realizing targeted transformational processes. The scope of the interventions in the medium-sized city (and region) in the preparatory period of organising the exhibitions enabled the measurability of urban morphology changes also at higher levels of resolution.

The organisation of the same event type in the same urban entity with an interval of sixty years enabled a comparative analysis of the composition changes of the urban structure components, constructive elements of the urban tissue pattern and the formative elements of the fundamental morphological unit according to the Conzenian rules of urban morphology.

ACE, 15 (44) CC BY-ND 3.0 ES | UPC Barcelona, España | World Exhibitions and Changes in the Urban Morphology 23 of Seville. DOI: http://dx.doi.org/10.5821/ace.15.44.8762 
The impact of the interventions on the composition of Seville's urban structure (level 4.1) realised on the occasion of organising the exhibitions EIA 1929 and EXPO 1992, shows in both cases the inverse relationship of the compactness coefficient and the coefficient of interaction with the environment. On the occasion of EIA 1929 a significant step forward was made in the area of future urbanisation, and the interventions carried out on the occasion of EXPO 1992 significantly contributed to the compacting of the urban structure composition.

The results of the analyses of traffic infrastructure at the second level of resolution (4.2 A) point to a discrepancy between the expected and the obtained research results related to the share of different categories of roads in the observed area. This is primarily due to the position of the exhibition areas in the composition of the urban structure of Seville, the conceptual features of the intent of organising a large event and the traffic solution of the exhibition areas.

The analyses of the constructive elements of the urban tissue texture (4.2 B) show an equal share of green and unbuilt areas in the total area of the observed samples. In the example of EIA 1929, this is due to the distinguished character of each individual element design of the urban tissue texture, while in the case of EXPO 1992 it is due to the concept of fragmentation of public open spaces in order to achieve better interaction between clusters of greater building density and open public spaces.

The results obtained from the analyses of the representative samples of fundamental morphological units (4.3) of EIA 1929 and EXPO 1992 indicate the most noticeable differences in the changes of the characteristics of generative elements in all investigated relations due to the changes in the typological characteristics of urban fabrics.

The application of more than twenty indicators (see Table 1) of the urban morphology elements built diachronically on the occasion of the same type of event (a world exhibition), on the same object (Seville), enables the operationalization and scientific evaluation of the spatial changes.

The hierarchy of traffic connections with the surroundings (urban system) and urban structure (city), the texture of constructive elements of the urban tissue, the functional diversity and design planimetric and stereometric opportunities for the creation of urban tissue of the observed components evidently demonstrate the complexity of urban morphology analysis.

Conflict of interest: Authors declare that there is no conflict of interests.

\section{Bibliography}

Busquets, J. (2005). Barcelona: the urban evolution of a compact city. Cambridge - Rovereto, USA Italy: Harvard University - Nicolodi editore.

Castells, M., \& Hall, P. (1990). El Desafio Andaluz: Modernización Tecnológica y Desarrollo Económico en Andalucía. Seville, Spain: Expo'92 Sevilla.

Castells, M., \& Hall, P. (1994). Technopoles of the world: the making of twenty-first-century industrial complexes. London, UK: Routledge.

Cortés José, J., García Jaén, M. J., \& Zoido Naranjo, F. (1992). Planos de Sevilla: Colección Histórica (1771-1918). Sevilla, Spain: Servicio de Publicaciones del Ayuntamiento de Sevilla and Editorial MAD, D.L.

Curdes, G. (1997). Stadtstruktur und Stadgestaltung. 2nd ed. Stuttgart, Köln, Germany: Kohhammer. Exposición Ibero-Americana Sevilla 1929-1930. Catálogo Oficial. (1929). Barcelona, Spain: J. Horta.

ACE, 15 (44) CC BY-ND 3.0 ES | UPC Barcelona, España | World Exhibitions and Changes in the Urban Morphology 24 of Seville. DOI: http://dx.doi.org/10.5821/ace.15.44.8762 
García Martín, F. M. (2019). Los valores de compacidad y densidad en los tejidos residenciales de la periferia de las ciudades intermedias españolas a lo largo del siglo XX. ACE: Architecture, City and Environment, 14(40), 11-34. DOI: http://dx.doi.org/10.5821/ace.14.40.5690

Gerencia de Urbanismo - Ayuntamiento de Sevilla. (2006). Plan General de Ordenación Urbanística Sevilla: Memoria de información. Retrieved from https://www.urbanismosevilla.org

Gutkind, E. A. (1967). International History of City Development. Volume III. Urban Development in Southern Europe: Spain and Portugal. London, UK: Collier-Macmillian Limited.

Levy, A. (1999). Urban morphology and problem of the modern urban fabric: some questions for research. Urban Morphology, 3(2), 79-85.

Levy, A. (2005). New orientation in urban morphology. Urban Morphology, 9(1), 50-53.

Marchena Gómez, M. J., \& Hernández Martín, E. (2016). Sevilla en la primera década del siglo XXI: transformaciones urbanas hacia un nuevo modelo de ciudad. Boletín de la Asociación de Geógrafos Españoles, 70, 393-417. DOI: http://dx.doi.org/10.21138/bage.2176

Meyer - Künzel, M. (2001). Der planbare Nutzen: Stadtentwicklung durch Weltausstellungen und Olympische Spiele. Hamburg - München, Germany: Dölling und Galitz Verlag.

Niño Soto, A. S., Badillo Jimenez, W. L., \& Dávila Cordido, M. (2019). Indicadores urbanos como instrumento de análisis para el diseño de proyectos de espacio público. ACE: Architecture, City and Environment, 13(39), 75-104. DOI: http://dx.doi.org/10.5821/ace.13.39.5366

Oliveira, V. (2013). Morpho: a methodology for assessing urban form. Urban Morphology, 17(1), 21-33.

Petrović Krajnik, L. (2011). Utjecaj odabira lokacija svjetskih i međunarodnih izložbi na širenje urbane strukture Bruxellesa [Impact of the Selection of World and International Exhibition locations on the Expansion of Brussels' Urban Structure]. Prostor, 19, 1(41), 126-135.

Petrović Krajnik, L., Petrović, V., \& Krajnik, D. (July, 2017). Dimensioning of Matrix of Urban Structures Complexity - Functional Paradigm. In: J. Antunes Ferreira et al. (Eds.), AESOP Annual Congress'17 Spaces of dialog for places of dignity: Fostering the European Dimension of Planning (pp. 2870-2877). Lisbon, Portugal: Universidade de Lisboa.

Petrović, L. (2009). Impact of World Exhibition on Urban and Regional Development. (Doctoral thesis). Graz University of Technology, Graz.

Petrović, V., Petrović Krajnik, L., \& Krajnik, D. (July, 2014). Dimensioning of Matrix of Urban Structures Complexity - Relational Paradigm. Work presented at the AESOP Annual Congress 2014 From control to co-evolution 2014, Utrecht / Delft, Netherland.

Pinot de Villechenon, F. (2000). Fêtes géantes: Les expositions universelles, pour quoi faire ? Paris, France: Editions Autrements.

Rispa, R., De los Rios, C. A., \& Aguaza, M. J. (1992). Expo'92 Seville: Architecture and Design. Milano, Italy: Sociedad Estatal para la Exposición Universal de Sevilla 92, \& Electa Elemond Editori Associati.

Rodríguez Bernal, E. (1994). La Exposición ibero-americana de Sevilla. Sevilla, Spain: Biblioteca de temas Sevillanos.

Scheer, B. C. (2016). The epistemology of urban morphology. Urban Morphology, 20(1), 5-17.

Sociedad Estatal de Gestión de Activos, S.A. (Ed.). (1993). Memoria General de la Exposición Universal Sevilla 1992, 1993. Sevilla, Spain: Sociedad Estatal de Gestión de Activos, S.A. (antes EXPO'92) and Ministerio de la Presidencia.

Whitehand, J. W. R (2001). British urban morphology: the Conzenian tradition. Urban Morphology, 5(2), 103-109.

ACE, 15 (44) CC BY-ND 3.0 ES | UPC Barcelona, España | World Exhibitions and Changes in the Urban Morphology 25 of Seville. DOI: http://dx.doi.org/10.5821/ace.15.44.8762 